$\begin{array}{llllllllllll}\text { R } & \text { E } & \text { D } & \text { U } & \text { T } & \text { A } & \text { A } & \text { G } & \text { A } & \text { I } & \text { N }\end{array}$

PAMIĘTNIK TEATRALNY 2020/2 (274)

ISSN 0031-0522, e-ISSN 2658-2899

INSTYTUT SZTUKI PAN

DOI: $10.36744 /$ pt.38

Wanda Świątkowska

Jagiellonian University in Kraków

ORCID: 0000-0002-8470-5643

\title{
THEATRE EDUCATION AT REDUTA
}

Ksztalcenie w Reducie 


\begin{abstract}
The article presents the history and principles of theatre education at Reduta in its successive forms: from Koło Adeptów [The Apprentice Circle], established in 1921, through the Reduta Institute, to Okop [The Trench], which was the last pre-war incarnation of the school. Based on documents and memoirs, the article discusses Reduta's comprehensive and holistic model of education, in which regular theoretical classes were accompanied by practical and physical exercises. A crucial part of the education process was student participation in the theatre's daily operations: rehearsals, preparation of stage productions, and tours. The aim of the school was to offer future artists comprehensive preparation for various theatre functions, as well as to produce ideologically engaged social activists, who consider serving the society through art as their primary task and mission. A comparison between Reduta's schools and other educational initiatives confirms that in terms of scope, curriculum, work methods, practices, as well as atmosphere, the former were indeed pioneering and stood out from traditional pre-war drama teaching. Published as an appendix to the article is its source material (in Polish): Juliusz Osterwa, Okop, edited and with an introduction by the author of the article. (Transl. Z. Ziemann)
\end{abstract}

Keywords: Reduta, Reduta Institute, Juliusz Osterwa, theatre education, theatre laboratory

\begin{abstract}
Abstrakt: Artykuł przedstawia historię i założenia edukacji teatralnej w Reducie na różnych etapach funkcjonowania zespołu - od powołanego w 1921 Koła Adeptów, przez Instytut Reduty po Okop, który był ostatnim przedwojennym wcieleniem uczelni. Na podstawie dokumentów oraz wspomnień ukazano wszechstronny i holistyczny model kształcenia, w którym regularnym zajęciom teoretycznym towarzyszyły ćwiczenia praktyczne oraz fizyczne. Zasadniczą część edukacji w Reducie stanowiła praktyka realizowana poprzez udział adeptów w codziennej pracy teatru: w próbach, w przygotowaniu przedstawień, w objazdach Reduty. Celem szkoły było kompleksowe przygotowanie artysty do pełnienia różnych funkcji w teatrze, jak również ideowe wychowanie społecznika, który służbę społeczeństwu poprzez sztukę uważa za swoje podstawowe zadanie i posłannictwo. Porównanie redutowych szkół z innymi inicjatywami pedagogicznymi potwierdza, że pod względem rozmachu, programu nauczania, sposobu pracy, praktyk, jak również tworzonej atmosfery miały one pionierski charakter i wyróżniały się na tle przedwojennego szkolnictwa dramatycznego. Aneksem do artykułu jest materiał źródłowy: Juliusz Osterwa, Okop, ze wstępem i w opracowaniu autorki artykułu.
\end{abstract}

Słowa kluczowe: Reduta, Instytut Reduty, Juliusz Osterwa, szkolnictwo teatralne, laboratorium teatralne 
$\mathrm{T}$ The famous Polish interwar theatre Reduta ${ }^{1}$ not only produced plays, but also constituted a space for experimental work as well as educational and social initiatives, as has been convincingly demonstrated by Zbigniew Osiński ${ }^{2}$. In my research, too, I have shifted the emphasis from Reduta as a repertory theatre to Reduta as an institute of theatre studies (as the co-founder Juliusz Osterwa used to call it in the second Warsaw period), i.e. a cultural, educational, and research institution. In 1931, Osterwa defined the aims of the Reduta Institute in a press interview: "The Institute will hold presentations and lectures on the problems of theatre (which are interesting also to the audiences) as a cultural and social institution. An advisory service for amateur theatres is being designed, as well as courses for directors working in such theatres"3. Stage competitions were planned and so was research on a reform of the Polish school of drama and on a model school theatre. The Institute's task was to "solve modern theatre problems and pave the way for a reorganisation of theatre"4. Osterwa envisaged a completely new institution, combining a theatre understood as a venue for stagings with an art academy, an advisory service for artists, a studio for research on drama and acting technique, a place of public lectures ('literary morning readings'), a library, an

${ }^{1}$ Reduta's history is divided into three periods: the first Warsaw Reduta (1919-1924), when the theatre was housed in the ballrooms of Warsaw's Teatr Wielki [although the Polish noun reduta does indeed mean redoubt, as the name of the theatre is sometimes translated into English, it is also a now obsolete word for a ball or a masquerade; originally, the theatre name played on both these meanings - translator's note]; Vilnius Reduta (1925-1931), when it relocated to Teatr na Pohulance in Vilnius and then to Grodno; and the second Warsaw Reduta (1931-1939), when it occupied the basements of the General Mutual Insurance Company building at ul. Kopernika 36/40 in Warsaw. See D. Kosiński, Performing Poland: Rethinking Histories and Theatres, transl. P. Vickers, Cardiff 2019.

${ }^{2}$ See especially: Z. Osiński, Instytut Reduty jako laboratorium teatralne, [in:] idem, Pamięć Reduty. Osterwa, Limanowski, Grotowski, Gdańsk 2003, pp. 65-110; idem, Returning to the Subject: The Heritage of Reduta in Grotowski's Laboratory Theatre, transl. K. Salata, „TDR - The Drama Review” 198 (Summer 2008), pp. 52-74; idem, Grotowski and the Reduta Tradition, transl. K. Salata, [in:] Grotowski's Empty Room, ed. P. Allain, London - New York - Calcutta 2009, pp. 19-54.

${ }^{3}$ Po sześciu latach nieobecności Reduta powraca do Warszawy, [in:] J. Osterwa, Reduta i teatr. Artykuty, wywiady, wspomnienia 1914-1947, ed. Z. Osiński, Wrocław 1991, p. 145. Cf. J. Osterwa, Through Theatre, Beyond Theatre, ed. I. Guszpit, transl. P. Vickers, Aberystwyth [in print].

${ }^{4}$ Wywiad z Juliuszem Osterwa, [in:] J. Osterwa, Reduta i teatr..., op. cit., p. 147. 
archive, a publishing house, as well as three separate units: School Theatre, Radio Studio, and Touring Ensemble. The focus of the present paper is Reduta's activity in the area of theatre education.

My aim here is to present the history and the essential premises of theatre education carried out at Reduta over almost twenty years. The Institute's educational methods and daily operations will be discussed based on personal memories and testimonies, better suited to creating a vivid picture than lifeless charters and regulations. The article uses unpublished archival material from Juliusz Osterwa's notebook kept between June and September $1939^{5}$. His notes on the organisation of the school year and the principles of teaching at Okop ("The Trench") - as the Reduta school was christened towards the end of its activity - testify to Osterwa's twenty years' experience as a teacher and school manager. These materials not only confirm that education was inherently linked to the ideological premises of Reduta as a theatre company, but also demonstrate the experimental character of the teaching curriculum.

\section{TWO MODELS OF EDUCATION}

Reduta's approach to performer training, which can be described as a studio model, differed from the academic model of the interwar period, represented by the State Institute of Theatre Art (PIST), established in 1932 as a continuation of the Department of Drama at the State Music Conservatory. The differences between the Reduta Institute, headed by Osterwa and Limanowski, and PIST, under the direction of Aleksander Zelwerowicz and Leon Schiller, lay not only in the curriculum and location, but also in the respective traditions from which they originated. The studio model should be associated with the activity of theatre ensembles focused on working with the actor, seeking new acting and staging methods, as well as exhibiting ideological commitment and concern for professional ethics. This approach was represented on the one hand by Russian and Ukrainian studios, ${ }^{6}$ e.g. the First Studio of the Moscow Art Theatre, the Vakhtangov Studio, or Berezil Theatre of Les Kurbas, and Jacques Copeau's Théâtre du Vieux-Colombier on the other. In the laboratories emerging in theatre ensembles, training was closely tied to practice, and the students gained experience on a professional stage. This, among other things, distinguished this model from education at the PIST, where Zelwerowicz banned students from performing in professional theatres, because he believed that this would distract them from schoolwork and instigate bad habits. As Zbigniew Wilski put it,

\footnotetext{
${ }^{5}$ See appendix to the present article.

${ }^{6}$ See e.g. K. Osińska, Klasztory i laboratoria. Rosyjskie studia teatralne: Stanistawski, Meyerhold, Sulerżycki, Wachtangow, Gdańsk 2003.
} 
Juliusz Osterwa and Mieczysław Limanowski chose to teach the acting profession in a different manner than it was done at the Department of Drama. Students of the Reduta Institute . . were above all else obliged to take part in all rehearsals of plays currently in the theatre programme, to watch the older actors perform and to prepare their roles in these plays. . . . [Although] over almost two decades the forms of work at the Institute would change, as would Osterwa's assistants, the main principle remained untouched, namely that the young people would learn the art of theatre though more or less indirect participation in preparing performances. Under this system, regarded as the invention of Konstantin Stanislavski and Jacques Copeau in Europe, students always gathered around an outstanding artistic personality, whose goal was not only to provide professional education, but also to create a new type of actor ${ }^{7}$.

Osterwa witnessed the work of Russian studios during his forced stay in Russia; in 1916, he met Konstantin Stanislavski and visited the First Studio ${ }^{8}$. Around the same time, Limanowski took part in rehearsals for Dostoyevsky's The Village of Stepanchikovo. In 1917, in Kiev, Osterwa came into contact with Stanisława Wysocka's Studya theatre, which drew on the Moscow tradition; here, the preparation of performances was as important as the training using the studio method.

That said, in the case of Reduta and its activities, it would be a simplification to speak of 'dependence' or 'influence'; we should rather see this as a case of a creative ferment, which in the first decades of the $20^{\text {th }}$ century gave rise to similar yet independent phenomena throughout Europe. The reformers certainly had one thing in common: for them, theatre was not a "business" but an "undertaking", as Osterwa explicitly called it.

Another major difference between the studio method and the PIST approach concerned the specialisation of theatre professions. Although the PIST was initially meant to comprise four departments: acting, directing, film and theatre, in the end only two were created: the Department of the Art of Acting (est. 1932), headed by Aleksander Zelwerowicz, and the Department of the Art of Directing (est. 1933), headed by Leon Schiller. As Wilski noted, "for the first time in Poland, an independent state institution was established with the sole purpose of educating artists of the theatre: actors, directors and set designers"9. The Reduta Institute,

7 Z. Wilski, Szkolnictwo teatralne, [in:] Teatr - widowisko, ed. M. Fik, Warszawa 2000, p. 522. Cf. also: idem, Polskie szkolnictwo teatralne 1811-1944, Wrocław 1978; K. Braun, Theater Training in Poland, [in:] Performer Training: Developments Across Cultures, ed. I. Watson, London - New York 2001, p. 13-32.

${ }^{8}$ See J. Osterwa, Notatki do wspomnień, [in:] idem, Reduta i teatr..., op. cit., pp. 227-247. In April 1917 Osterwa wrote from Kiev to Mieczysław Szpakiewicz: “I know Stanislavski’s Studio. Enjoying his favour, I got to know the Moscow organisation, and I was overwhelmed on seeing in real life the preoccupations that I'd jotted down in my notebooks", Listy Juliusza Osterwy, ed. E. Krasiński, introduction J. Zawieyski, Warszawa 1968, p. 50.

${ }^{9}$ Z. Wilski, op. cit., p. 521. 
on the other hand, educated people of the theatre: versatile artists, always focused on self-development, and dedicated social activists - as postulated by Stanisław Wyspiański in his Hamlet Study ${ }^{10}$. Osterwa himself said in an interview in 1921:

The ideal actor, the "man of theatre" according to Wyspiański, knows everything that theatre is made of, all the individual components; [the ideal is] universality and self-sufficiency ${ }^{11}$.

The aim of the Reduta Institute then was not only to train actors in their craft, but also to prepare them comprehensively for various kinds of theatre work, to make sure they develop professional ethos, to encourage them to work on themselves continuously, "to instill in them respect for the profession and love for art" 12 , as well as to teach them that their work means "service to art and society"13.

Thus, unlike the academic model, the studio model was an original training programme created to function at particular theatre ensembles, subordinated to the ideological and ethical principles developed by them and manifested in their activity, in which the students were deeply involved. In this article, I would like to emphasise two fundamental aspects of the studio model of performer training, which I see as the most important characteristics distinguishing Reduta's educational system: its versatility and holistic nature (education focused not only on the acting technique, but on something we might call personal character and the development of an ethos) and its practical dimension (engaging students in the daily operations of Reduta, in preparing performances and tours).

\section{THE INSTITUTE'S PREMISES AND AIMS}

Educational activity already began in Reduta's second year of operation. In October 1921, the Apprentice Circle (Koło Adeptów) was established, to be transformed a year later into the Reduta Institute - a school combining acting training with work for Reduta. The Institute operated, with intermissions, until the outbreak of World War II; during the Vilnius period, from summer 1925 to July 1929, the Institute's functioning was suspended due to financial problems ${ }^{14}$. During the last two years of its activity (from October 1937), in line with the military nomenclature invented by Osterwa, the school became known as "The Trench" (Okop).

${ }^{10}$ S. Wyspiański, The Hamlet Study and The Death of Ophelia, transl. B. Bogoczek, T. Howard, London 2019.

${ }^{11}$ E.W. [E. Wierciński], Wywiad z Juliuszem Osterwa, [in:] idem, Notatki i teksty z lat 1921-55, ed. A. Chojnacka, Wrocław 1990, p. 24.

12 Z. Osiński, Pamięć..., op. cit., p. 92; cf. K. Jeżewska, Teatr Szkolny Reduty, [in:] O Zespole Reduty 1919-1939. Wspomnienia, Warszawa 1970, pp. 294-295.

${ }^{13}$ K. Jeżewska, op. cit., p. 295.

${ }^{14}$ See Z. Osiński, Pamięć..., op. cit., p. 38. The Reduta Institute reopened on $25^{\text {th }}$ July 1929. 


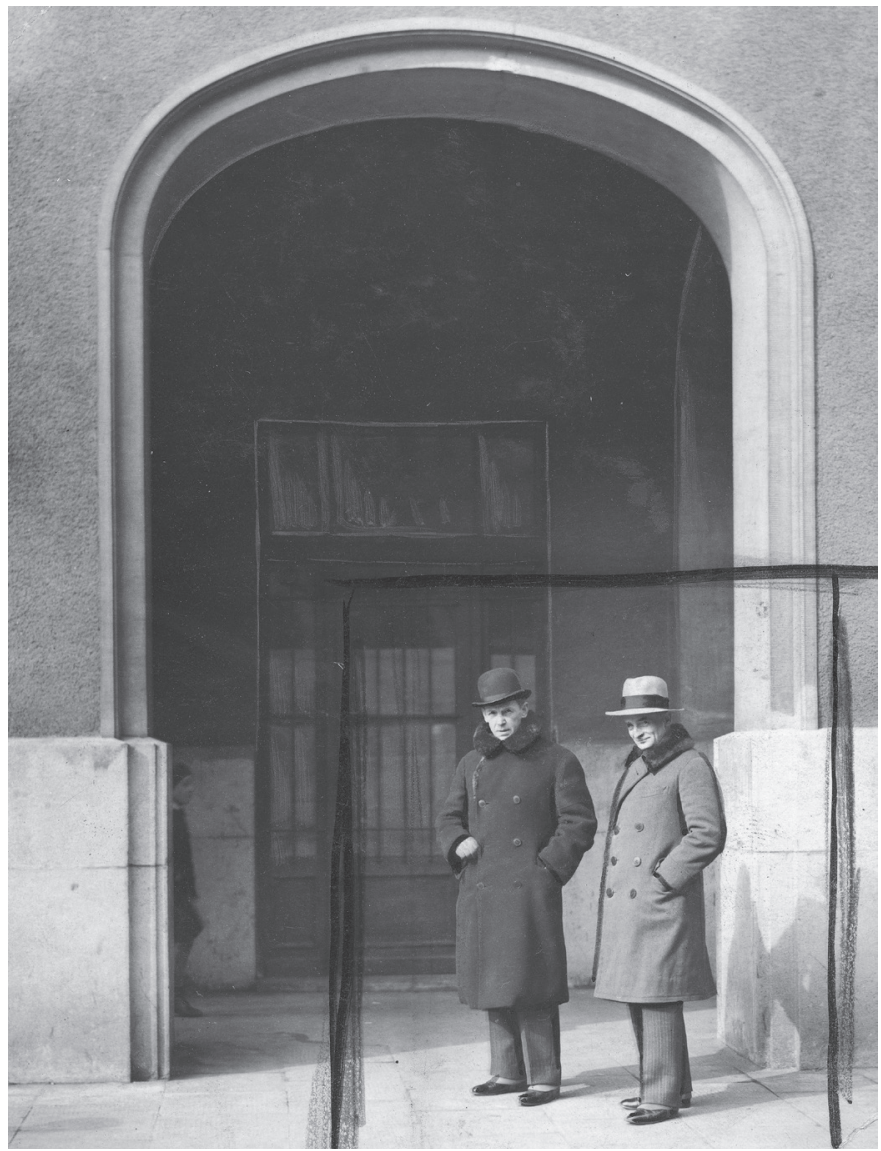

Juliusz Osterwa and Tadeusz Białkowski in front of the Reduta Institute in Warszawa, 1931, National Digital Archives

The educational mission was officially recognised in Reduta's charters: the 1923 Charter states that "establishing and running the academy in compliance with the relevant regulations of the Ministry of Religious Denominations and Public Enlightenment and theatre institutes" is one of Reduta's goals, while the 1938 Charter further specifies in the second paragraph that the goal of the Artistic Association named "The Reduta Company" is:

a) the consolidation and self-education of a group of Polish theatre activists, who believe that gathering knowledge and perfecting their skills in theatre art and management are their mission in the service of the Art and Culture of the Nation ${ }^{15}$.

151923 and 1938 Charters, [in:] J. Osterwa, Reduta i teatr..., op. cit., pp. 342-349. 
This should be achieved through: "organising and running institutes and academies", "setting up archives, collections, reading rooms, libraries, studios", "publishing periodicals, pamphlets and books on theatre", "organising public lectures, meetings, and artistic undertakings", "opening a boarding house for members", "organising summer camps", among other things.

In the programme of the Reduta Institute for 1924/1925, Edmund Wierciński described its aim as "Striving to create an artist type of actor, aware of his spiritual, artistic and national tasks"16. Osterwa used to call the Institute a "school for rearing actors"17 and stressed the importance of "educating the young actor in social terms", shaping his or her moral attitude and a serious approach to the profession ${ }^{18}$. "The actor", he claimed, "must be comprehensively educated and never cease working on himself as long as he is in the profession"19. The aim of the Institute was to develop a "Reduter" ethos, and even, as Zbigniew Osiński wrote, "to form a person through the most comprehensive and profound possible influence. In this case, one can speak of quite far-reaching coincidences with the ancient Greek paideia - though in a completely different cultural context... It was the practice of «growing up to humanity»" 20 .

This distinctive feature of Reduta's educational system is also mentioned in a recollection by its former student, Hanna Małkowska:

The difference between the Reduta Institute and other acting schools lay not only in the "studio" work, quite unlike the regular hours of school lectures, but above all in the educational principles. Osterwa was not interested in teaching actors, even most thoroughly, to "play parts". At the Institue, he wanted to educate not just an actor but above all a man of theatre, to whom no performance-related domain would be alien. We were drawn into the totality of theatre work, into the theatre's all nooks and crannies; we grew one with the theatre not as with a workplace but as with the place of our whole existence ${ }^{21}$.

According to Małkowska, given Osterwa's plans to reform the Polish theatre and to create a new style of acting, establishing a school at Reduta was a necessity: "Osterwa wanted to bring up the youth, a new acting generation, educated in a different method and climate than those of the drama schools of the day" 22 . This "different method" required a new approach to students, who would gradually become

${ }^{16}$ E. Wierciński, Program Instytutu Reduty w Warszawie (1924-1925), qtd after: Z. Osiński, Pamięć..., op. cit., p. 546.

${ }^{17}$ Wywiad z Juliuszem Osterwa, op. cit., p. 145.

${ }_{18}$ See K. Jeżewska, op. cit., p. 294.

${ }^{19}$ Ibidem, p. 295.

20 Z. Osiński, Pamięć ..., op. cit., p. 109.

${ }^{21}$ H. Małkowska, Wspomnienie o pierwszym Instytucie Reduty, [in:] O Zespole..., op. cit., p. 87 [original emphasis].

22 Ibidem, p. 85. 


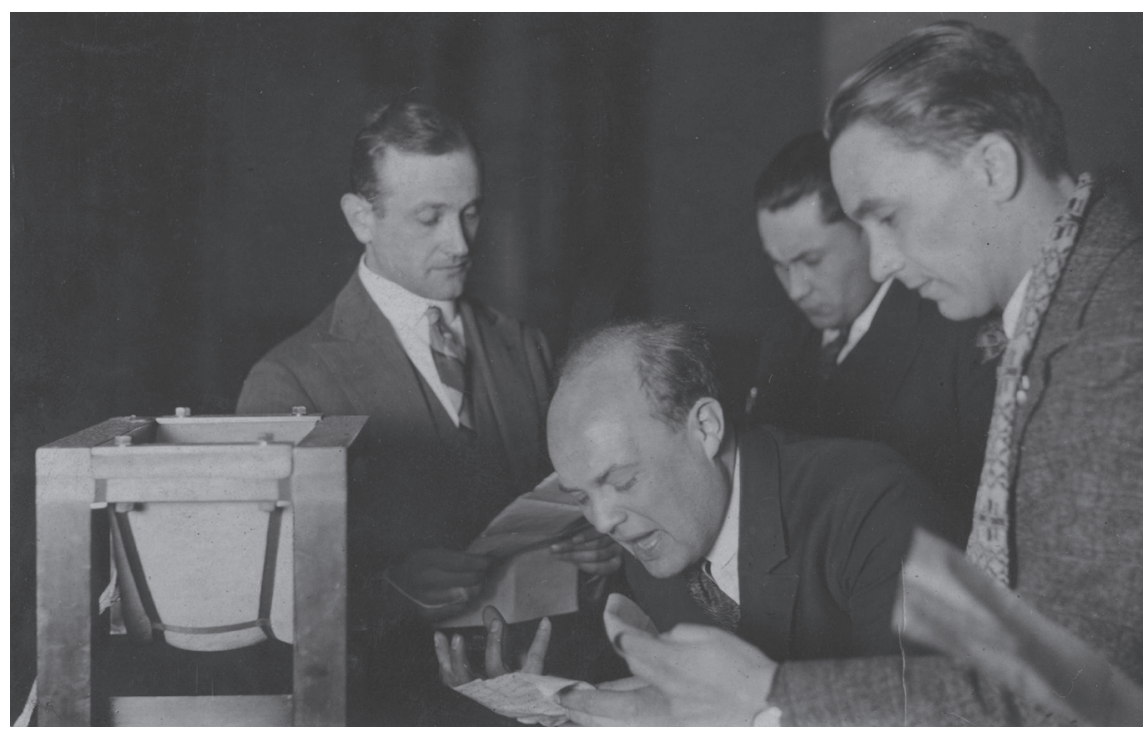

Saturnin Butkiewicz, Adam Mikołajewski, Stefan Brem, and Kazimierz Knobelsdorf reading Kasprowicz's Na wzgórzu śmierci [On the Hill of Death], Vilnius 1929, National Digital Archives

part of the ensemble, subject to the same rules as the rest ${ }^{23}$; indeed, many stayed on after graduation. For example, the first admissions round, before the school changed its name, included the future Reduta actors Kazimierz Brodzikowski and Ewa Kuncewiczowa, as well as Edmund Wierciński, who in 1924 became the director of the Institute after the tragical death of Józef Poremba. In the following years, the school admitted Konstanty Pągowski, Roman Zawistowski, Antoni Cwojdziński, Julia Kossowska, Maria Wiercińska, Stanisława Zbyszewska, Saturnin Butkiewicz, Tadeusz Byrski, Jacek Woszczerowicz, Mieczysław Pill, Dobiesław Damięcki, Ludwik Berger, and Helena Łopuszańska. Some of them stayed at Reduta for good, others left, but in their new theatres they promoted the principles and ethos of their alma mater ${ }^{24}$.

${ }^{23}$ See W. Świątkowska, Zespołowość Reduty, [in:] Czy tylko Reduta? Wspólnota - zespót - spótdzielnia twórcza - kolektyw w teatrze, Warszawa 2020, pp. 1-23, http://www.encyklopediateatru.pl/ ksiazka/774/czy-tylko-reduta-wspolnota-zespol-spoldzielnia-tworcza-kolektyw-w-teatrze [accessed: June 22, 2020].

${ }^{24}$ Reduta graduates became important figures of Polish post-war theatre and artistic life: actors, directors, playwrights, theatre managers or artistic directors, and eminent educators. Writing in the 1950s, Jerzy Szaniawski observed: "There seems to be no theatre in Poland where you wouldn't meet a Reduter. Many of them manage theatres, others are theatre directors, sometimes outstanding. It is easy to see in their work things familiar from the theatre and school that they came from", J. Szaniawski, Reduta, [in:] idem, W pobliżu teatru, Kraków 1956, pp. 231-232. 
Hundreds of actors passed through the Reduta school (thanks to Ludwik Simon's inventories, the memoirs of the Reduters themselves, and the research of Zbigniew Osiński, 150 people are known by name); every year, between a dozen or so (fourteen in the Apprentice Circle 1921/1922) and thirty entrants were admitted. Selection was inevitable, since already in September 1922 more than fifty candidates applied; twenty got accepted. In 1924, there were over a hundred candidates. These were young people - secondary school graduates or university students, usually without theatre experience. The entrance exams took several days, thoroughly checking the candidates' predispositions: from physical condition (with a medical doctor on the panel), through skills (reciting verse and prose) to motivation (interviews conducted first by Limanowski, then Wierciński). Candidates were also required to write their resumes and discuss them before the panel. The atmosphere at those exams can be inferred from anecdotes. Tadeusz Byrski, for example, noted down two characteristic questions that Limanowski asked at his exam: "If you were Hamlet, which book would you be holding when walking around the gallery?" (Byrski said that it would have been Żeromski) and "What thoughts came to your mind during Sienkiewicz's funeral in Warsaw?" (the candidate replied that he was thinking about Słowacki's ashes) $)^{25}$.

Wierciński thus explained the reasons for such a strict selection:

Opening the Institute in the autumn of 1924, Reduta made a strict selection: out of 103 entrants, 16 were admitted as ordinary students, 5 as extraordinary students, 3 as candidates, and 6 persons remained from the previous year.

The reason for such selection was concern for a harmonious tuning of all [students] with the common high artistic and ideological level, without which Reduta's efforts to build a strong ensemble, enlivened by non-egoistic ideas, could have proven too difficult to succeed ${ }^{26}$.

Not everyone managed to persevere in the Reduta regime; some students left (for example, Konstanty Ildefons Gałczyński, Aleksander Matoga, and Juliusz Saloni studied at the Institute for only a few months ${ }^{27}$.

${ }^{25}$ Zob. T. Byrski, Jak to się stało, że znalazłem się w Reducie?, [in:] O Zespole ..., op. cit., pp. 172-173. In 1924, the ashes of Henryk Sienkiewicz were brought to Poland from Switzerland; they were buried ceremoniously on $27^{\text {th }}$ October in the tombs of St. John's Cathedral in Warsaw. See also K. Salata, Reduta's Reorigination of Theatre. Radical Collectivity in Poland's Interwar Theatre Laboratory, [in:] A History of Collective Creation, eds. K. M. Syssoyeva, S. Proudfitt, New York 2013, pp. 59-69.

${ }^{26}$ E. Wierciński, Program ..., op. cit., p. 546.

27 See Z. Osiński, Pamięć..., op. cit., p. 622. As a laboratory, Reduta attracted artists (poets, visual artists, musicians) and scientists. They often contributed to the preparation of performances or taught at the Institute, but sometimes the collaboration proved disappointing for both sides, as in the case of the temporary students listed above. 


\section{TEACHING METHODS}

The day of an Institute student was filled with activities from 10 a.m. to 10 p.m. During the day, there were theoretical classes and practical exercises. Students took part in rehearsals for the current stage productions, and in the evenings they performed as extras or they helped in other auxiliary capacities (with stage management, set decoration and costumes, light, technical work). They also had shifts in the audience. They shared non-artistic responsibilities as well- housekeeping and cleaning chores, administrative work, ticket sales, and helping in the kitchen. As Ireneusz Guszpit ${ }^{28}$ emphasised, students underwent a kind of "novitiate", and those who remained after that period were the most persistent ones, the most determined to serve the theatre. It usually lasted for two years, but it was possible to rise through the ranks more quickly (Edmund Wierciński took a replacement role after just two months at the Institute). Michał Orlicz wrote that one of the ways of "arousing enthusiasm" was to "throw untrained apprentices on the stage front," to entrust to them (sometimes without preparation) minor parts or deploy them as extras so that "they would get used to the view of the lamps and backstage, and the looks prickling them from the audience"29. During the second Warsaw period (1931-1939), students played at the School Theatre, and they took part in morning poetry readings and in radio broadcasts ${ }^{30}$. Not only did they gain experience, but most of all they learnt how to work as a team.

Students sometimes found the backstage work difficult, but Osterwa insisted on it, because he believed that a future actor must learn every kind of theatrerelated skill. This sometimes led to funny situations, as in Leokadia MichałowskaZaręba's reminiscence about her time at the Institute:

Once, I recall, I served "as an electrician", because at the Institute we were taught that too. Upon $\mathrm{Mr}$ Juliusz's exit as Przełęcki in My Quail Has Fled, I was to dim the lights on the rheostat. I don't know what happened, but instead of dimming, I lit everything up, including the audience. I thought I'd faint for fear and shame. The next day I was told off by Master himself, in front of what I remember as all of Reduta. He ranted and raved at my poor self, but everyone else, too, got their share on the occasion. Standing in a semicircle in Mr Juliusz's study, we listened attentively and humbly to his address about the priesthood of art, the role of artists and their social mission, about humility and professional responsibility. In that moment, I disliked Mr Juliusz very much as he spoke to us, walking around the room with his hands behind his back. Later I begged him to exempt me from those horrid shifts, explaining that I'm really no good at that, I can't, I don't know how - but to no avail. After a month, perhaps even sooner, I managed to earn his praise ${ }^{31}$.

${ }^{28}$ I. Guszpit, Wstęp, [in:] J. Osterwa, Przez teatr-poza teatr, eds. I. Guszpit, D. Kosiński, Kraków 2004, p. 52.

${ }^{29}$ M. Orlicz, Polski teatr wspótczesny. Próba syntezy, Warszawa 1935, p. 131.

${ }^{30}$ See L. Michałowska-Zaręba, Okop 1938/39, [in:] O Zespole..., op. cit., p. 365.

31 Ibidem, pp. 356-357. 
Apart from practical skills and thorough knowledge of how a theatre operates as an institution, such apprenticeship taught students respect for auxiliary, nonartistic roles. This is a recurring motif in the reminiscences: "even the tiniest form of participation in the operations of the theatre gave us satisfaction, because Osterwa always emphasised the parity of all theatre tasks" 32 ; "We have developed an awareness of the importance and necessity of all the elements of the performance, which, like a mosaic, had to be reassembled from tiny particles every night" ${ }^{\prime 3}$.

The teaching methods at the Reduta Institute were experimental and often unusual - also due to the colourful personalities of the teachers: the members of the Reduta Company. Tadeusz Byrski remembered that Osterwa sometimes made strange demands on students and that he hated to be contradicted. Once, when they were working on Easter, a play on the Passion, he demanded that they participate in a retreat at the Sisters Canonesses' church (including going to confession and receiving Communion, an idea that was met with mixed reactions), on another occasion they were to serve as local guides for the peasant delegations that came to Warsaw to celebrate the national holiday of the $3^{\text {rd }}$ of May, or to take care of Reduta's guests (collaborating authors, artists, members of the governing body). They also had to take part in social gatherings and soirees, as Osterwa explained that "a man of theatre must not avoid confrontation, and for an actor everything is useful" 34 . The idea was not only to comprehensively prepare the actors for their profession, but also for the various unusual obligations that they would face as artists. Byrski recalled:

Oh, how much bad blood there was because of those weekly soirees, and dinners, and balls. We had to play hosts everywhere. To entertain guests, to know how to represent the institution, how to justify our presence here. [Osterwa] was inexorable. He would literally take you by the hand and sit you among the guests, sometimes quite eminent, like Żeromski, Kamiński or Szaniawski (talking to him was a torture, as he was known to be a man of few words). I would break sweat, since I was more of a recluse, but he was right after all ${ }^{35}$.

The work at the Institute often took over personal life; meals and leisure time were spent together (for example, the students once went on summer holidays with the Reduta actors, where they rested together, but also worked). As Wierciński noted, "Among its collaborators and students, Reduta created the atmosphere of a family home, which manifested in a tangible way - apart from interpersonal relations - in sharing not only artistic, but also domestic life (shared budget, shared

\footnotetext{
${ }^{32}$ S. Sznaper-Zakrzewska, Szkoła wolna od walki i udręki, [in:] O Zespole..., op. cit., p. 348.

${ }^{33}$ H. Małkowska, op. cit., p. 87.

34 T. Byrski, op. cit., p. 180.

35 Ibidem, p. 183.
} 
breakfasts, dinners, etc.)"36. "Reduta preoccupied people completely, filling their lives not only in terms of time ... but also spiritually", Byrski recollected ${ }^{37}$. The curriculum was designed to teach teamwork, educating a community based on the principles of camaraderie and friendship: a "model collective", as Osiński put $i^{38}$. Terms such as "home", "family", "community", "commune", and "convent" recur in the testimonies from the Institute's students. Interpreting this teaching approach, Zbigniew Osiński described the principles regulating the group's life thus:

The "Reduta family" model found its manifestation in the mutual relations between older Reduters (including some teachers from outside the company) and young students of the Institute, in their joint service for art's sake, in uniform work clothes, . . in communal economy: the Institute's students took shifts helping in the kitchen and at the table, they had a shared budget, and didn't get an actor's salary, unlike members of the acting ensemble, who, in turn, were all paid the same rate ${ }^{39}$.

The Institute became a common cause, a home - as remembered by Michał Orlicz:

A distinctive feature of the Reduta household were common meals, thanks to which a tradition emerged of company members taking shifts at the table, regardless of their position at Reduta; this involved a somewhat humorous, perhaps, but also pleasant role of personally serving one's colleagues, as well as hosting guests on behalf of Reduta ${ }^{40}$.

The Reduters and the students addressed one another by their first names, which served to create a feeling of kinship and a familial atmosphere. Osterwa designed a precise system of forms of address, as evident from his notebook titled [Reduta] Preparations ${ }^{41}$, containing an entry titled "Customary Reduta forms of address in mutual relations and collaboration":

In principle, the Reduta Company - in casual relations, among colleagues, in the course of Reduta collaboration - avoids using family names...

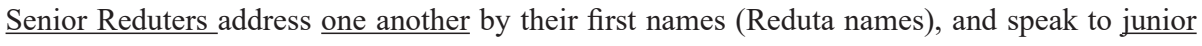
Reduters and candidates using the form "colleague", adding the familiar [diminutive - translator's note] form of the first name, to senior students "Mr" with the familiar first name, to j. [unior] stud. [ents] "Mr" with the Christian name [full form of first name - trans. note]...

${ }^{36}$ E. Wierciński, Program ..., op. cit., p. 546.

${ }^{37}$ T. Byrski, op. cit., p. 176-177.

${ }^{38}$ See Z. Osiński, Pamięć..., op. cit., p. 83.

${ }^{39}$ Ibidem, p. 35.

${ }^{40}$ M. Orlicz, op. cit., p. 158.

${ }^{41}$ The title "Preparations" comes from Osterwa, while the qualifier "Reduta" was added by his wife Matylda, hence my use of square brackets here. Written between June and September 1939, the notebook concerns the organisation of Okop and tours; it is kept at the Theatre Musem in Warsaw. 
Junior students address one another as: colleague + familiar name to seniors: colleague + Christian name to cand.[idates] and Red.[uters]: $\mathrm{Mr}+$ Christian name ${ }^{42}$.

This custom was a constant of Reduta's operations right from the start. Already in his credo of 1922, Redutowiec to ten... [A Reduter is...], Osterwa emphasised: "At Reduta, you don't have family names, there are first names, first names called" ${ }^{43}$. The "Reduta names" were special nick names, mostly diminutives. Featuring in Osterwa's letters are the following: Liman - Limanowski, Dziunio - Edmund Wierciński, Kocio - Konstanty Pągowski, Iwek - Iwo Gall, Duleczka/Dulka - Wanda Osterwa, Genio - Eugeniusz Bąbolski, Bryś - Tadeusza Byrski, Toś - Antoni Cwojdziński, Zbyś - Feliks Zbyszewski, Sotek - Saturnin Butkiewicz, Tila - Matylda Osterwa; they also recur in the Reduters' testimonies, which means that they were used on a daily basis, not just by Osterwa himself. One recollection mentions that Limanowski had an affectionate nickname for the students as a group: "Piplaje" ${ }^{4}$. This seemingly small detail also consolidated the group, just like the Reduta language introduced on a greater scale in Vilnus, where specific theatre vocabulary became a secret hermetic code of understanding at the Institute and at Reduta company.

A certain exclusiveness and elitism of the Reduta school was also evidenced by the often ridiculed "Reduta robes", designed by Iwo Gall, which served as a kind of school uniform and, at the same time, practical work clothing ${ }^{45}$. It was a long dress made of thin grey gabardine, tied at the waist with a rope, with wide slit and laced-up sleeves, a mid-chest yoke, and a square neckline. Underneath, students wore their own clothes or a gym suit; they could change quickly between theoretical and practical classes.

Reduta actors and staff were involved with the Institute, which was conducive to the emergence of master-disciple bonds. Byrski recalled: "in small groups, we were assigned to senior Reduters, whose duty was to watch over our individual work pretty much all day long" ${ }^{46}$. They conducted practical and theoretical classes. Thanks to Wierciński's notes reprinted by Zbigniew Osiński, we can reconstruct the Institute's curriculum for 1924/1925. "Technical elements of the art of acting" included courses in the following: diction (with Halina Gall), rhythm and body work (with Tacjanna Wysocka), fencing and athletics (with Capt. Wiktor Hutt), voice and breathing (with Karolina Pietraszewska), solfeggio and singing (with Eugeniusz Dziewulski and Mieczysław Pill) ${ }^{47}$.

\footnotetext{
${ }^{42}$ See J. Osterwa, Okop in the appendix.

${ }^{43}$ Idem, $Z$ zapisków, ed. I. Guszpit, Wrocław 1992, p. 61.

${ }^{44}$ See A. Wójcikiewicz-Rumlowa, op. cit., p. 341.

${ }^{45}$ See T. Byrski, op. cit., p. 178.

${ }^{46}$ Ibidem, p. 175.

${ }^{47}$ See E. Wierciński, Program ..., op. cit., s. 544.
} 


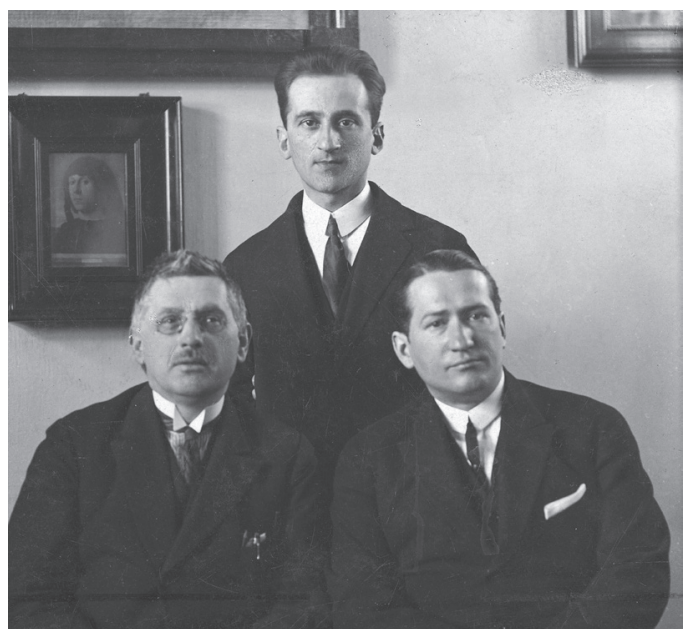

Mieczysław Limanowski, Iwo Gall, Jerzy Kossowski, Vilnius 1925, National Digital Archives

The second group of classes comprised the "Artistic elements of the art of acting", and was mainly under the charge of Mieczysław Limanowski, whose personality and character had a great influence on the Institute's students: "Limanowski was a revelation for me", Byrski recalled ${ }^{48}$. The teacher's methods of text analysis, conversation, ways of thinking and creating associations were certainly non-standard. This is evidenced in many anecdotes, for example in Stefania Kornacka's recollection of rehearsing the scene with Marysia and the Bride in Wyspiański's The Wedding:

At one point, there's a mention of a cow named Krasula. The scene wouldn't come together. When a colleague came to the Krasula bit, Mr Mieczysław interrupted her every time, saying that he didn't see, didn't "feel" that cow. The colleague ... tried out various ways of speaking - and never got it right. Finally, towards the end of the first hour of the class, Mr Limanowski shouted irritably: "Oh, do give birth to that cow, will you!"

It was only at the end of the second hour (and the whole time the colleague had to talk about that cow, what it looked like, how much milk it gave, what were its virtues and vices, whether it calved and what happened to the calves, and so on) that she managed do "give birth to a cow" 49 .

48 T. Byrski, op. cit., s. 176.

49 S. Kornacka, Teoria, [in:] O Zespole ..., op. cit., p. 141-142. The saying "to give birth to a cow" became part of the student lingo, denoting "artistically well-executed work", a success achieved with great toil, ibidem, p. 141. Cf. S. Srebrny, Limanowski w Reducie, [in:] idem, Teatr grecki i polski, ed. S. Gąsowski, Warszawa 1984, p. 643. 
"Limanowski was an emotionalist and intuitionist," Stefan Srebrny wrote in his memoirs. "He often came to the right conclusions in an astonishing way, intuitively, jumping over the whole sequence of links between the starting point and the final conclusion" ${ }^{50}$. He aroused the imagination of students and actors, provoked them, forced them to look for distant and unusual associations. Osiński stressed that Limanowski's found fulfilment primarily in teaching and laboratory work. When the Institute suspended his activity, he left Reduta and took over the geography department at the Stefan Batory University in Vilnius ${ }^{51}$. He returned only after the Institute resumed operation.

In 1924/1925, Limanowski taught the "Analysis of works intended for stage production" ("explaining the emotional, mental, and spiritual content of a work through collective inquiry and consensus"), "Reading" ("embracing the text with the truth of thought and feeling") and "Exercises leading to artistic realisation" of a work ("practical extraction of the characters' mental and spiritual values through contact and reactions") ${ }^{52}$. Other "Artistic elements" included exercises in poetry and silence (with Wierciński), gesticulation (with Iwo Gall), group improvisation, and acting techniques (with Osterwa and Stefan Jaracz). Byrski also recalled as "inspiring, innovative, often captivating" Osterwa's unusual exercises in the sense of time, looking into each other's eyes, concepts turned into gestures, conversations in savoir-vivre ${ }^{53}$. He stressed that the school curriculum was designed in such a way to integrate all classes, for example by combining exercises in fencing with verbal fencing (based on the text of The Wedding), text analysis with visual arts (under the guidance of Iwo Gall, students would work in wax and clay to make figurines of the characters from The Wedding, showing their temperament, behaviour and expression (a kind of "plastic composition of the character" ${ }^{54}$ ), or, in the case of Wierciński's classes, reading The Hamlet Study with elements of something that could be called "examination of conscience and an exercise in introspection" 55 . Thus, the matters of technique and craftsmanship were only one component of a comprehensive education.

The curriculum also included "seminar work of the Institute's students in the field of theatre", run by Eugeniusz Świerczewski and public guest lectures (obligatory for the students). From December 1924 to May 1925, eighteen lectures on theatre history took place on Sunday afternoons; for example, Stefan Srebrny and Tadeusz Zieliński talked about the Greeks, Andrzej Tretiak about Elizabethan

\footnotetext{
${ }^{50}$ S. Srebrny, op. cit., p. 635.

${ }^{51}$ See Z. Osiński, Pamięć..., op. cit., p. 89.

${ }^{52}$ See E. Wierciński, Program ..., op. cit., p. 545.

53 See T. Byrski, op. cit., p. 177.

${ }^{54}$ See M. Orlicz, op. cit., pp. 134-136; S. Kornacka, Teoria, op. cit., pp. 133-146.

55 T. Byrski, op. cit., p. 178.
} 
theatre, Władysław Folkierski about medieval French theatre, Józef Ujejski about Słowacki's drama, Tadeusz Sinko about Wyspiański, Zygmunt Łempicki about Goethe, Ludwik Bernacki about eighteenth-century Polish theatre, and Bohumil Vydra from the Charles University in Prague about the history of Czech theatre ${ }^{56}$.

As can be seen, the Institute's curriculum was wide-ranging and innovative. It went beyond acting technique, aiming to develop sensitivity, arouse imagination, and enhance the knowledge of culture. The students were trained not only in physical fitness, but also learnt how to focus their attention and energy; all in all, they, were comprehensively and practically prepared for the work of an actor, director, playwright, critic, theatre manager or artistic director.

For all these functions have so far relied on chance and favouritism and not on a system and education. The task of the Reduta Institute was to educate precisely these people and point them in the right direction. . . . It is common knowledge that the Reduta offspring has been the most in demand amid all theatre directors and milieus ${ }^{57}$.

The curriculum, the teaching methods, ways of working, practical training, and the atmosphere - all that made the Institute a pioneering school.

\section{OKOP}

In late 1930s, Osterwa worked intensively on the program of Okop, which was to replace the Institute as a professional "university with a strong program and regulations" 58 . Józef Szczublewski believed that this was a step towards "monasticisation and militarisation" 59 . Adam Sznaper recalls: "It was decided that young students of the art would be educated methodically towards the stage. The theatre institute was transformed into a school under the direction of Mrs Gall. It was christened as The Trench" 60 . The school began to function in October $1937^{61}$, under the charge of Tytus Dymek, a former student of the Institute.

At the entrance examination, the candidates had to demonstrate knowledge of the regulations and the Reduta Charter, as well as the works from the reading list (Słowacki's Letters to Mother, Norwid's Promethidion and Wyspiański's The Hamlet Study). They also had to undergo a preliminary medical examination, and, after being accepted, they had to get themselves a work coat and a gym suit. Stu-

${ }^{56}$ See M. Orlicz, op. cit., pp. 132-134.

${ }^{57}$ Ibidem, p. 131.

${ }^{58}$ Osterwa’s letter to T. Białkowski, 9 Oct. 1937, [in:] Listy Juliusza Osterwy, op. cit., p. 220.

59 J. Szczublewski, Żywot Osterwy, Warszawa 1973, p. 432.

${ }^{60}$ A. M. Sznaper, Pierwsze kroki, [in:] O Zespole..., op. cit., p. 325.

${ }^{61}$ See J. Szczublewski, op. cit., p. 432; cf. Listy Juliusza Osterwy, op. cit., p. 220; Z. Osiński, Pamięć..., op. cit., p. 90. 


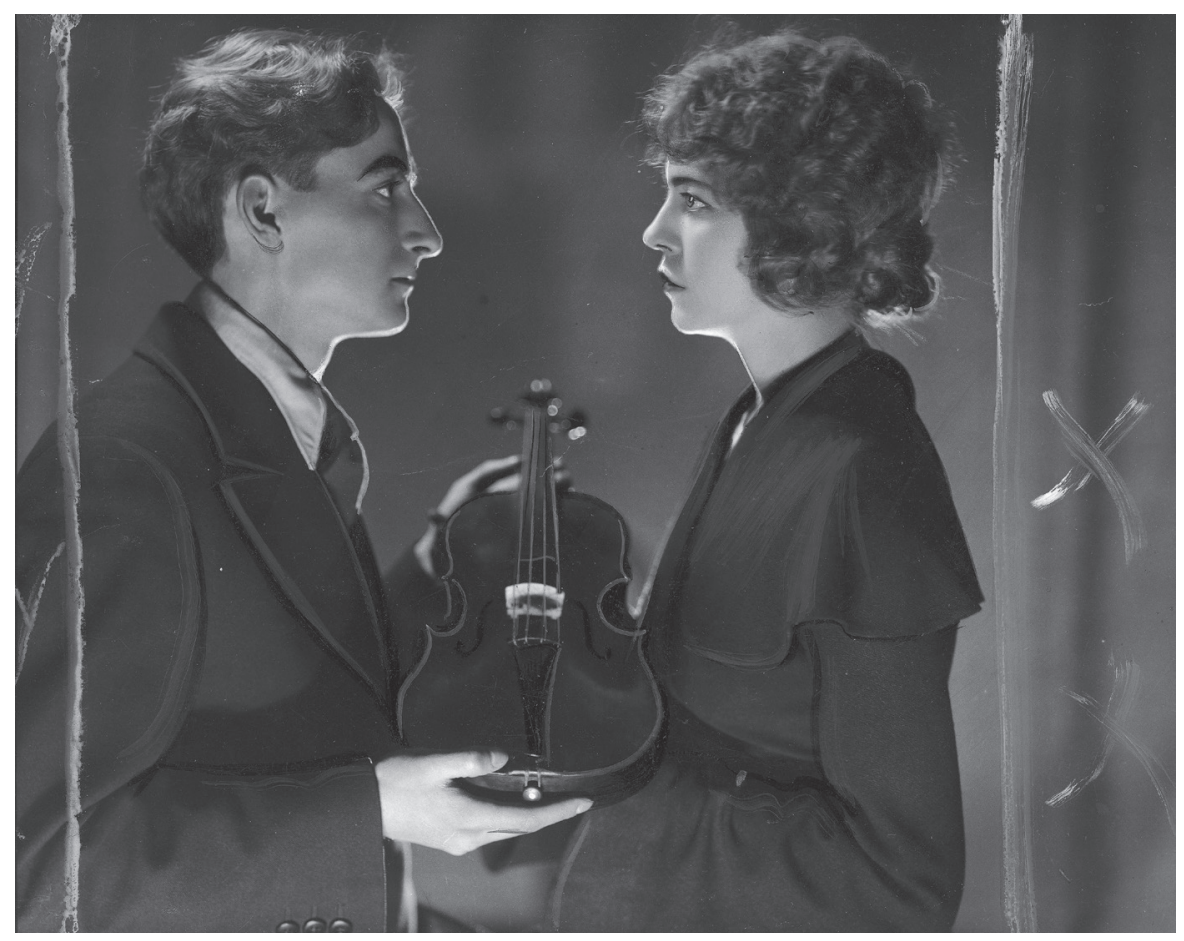

Rostand's The Man I Killed at the Reduta Institute in Warsaw,

Nina Świerczewska and Roman Zawistowski, 1933, National Digital Archives

dent obligations included: showing up on time for lectures and exercises, following the instructions of the Supervisor, paying the fee of a voluntarily pre-arranged amount, using Reduta vocabulary, and taking part in tours. Osterwa supplemented the curriculum with general subjects: Polish Geography and History, Polish Language, Grammar, Phonetics, Stylistics, as well as with lectures in the field of theatre (Polish Theatre, Polish State Artists Association), and Reduta-related subjects: Reduta Organisation, Regulations, Charter, Reduta Vocabulary, Touring Affairs. Practical exercises included breathing, voice, singing, silence, concentration, harmony, movement, rhythm, dance, enunciation, memory, fencing, poetry, and drawing. Students had to take shifts ("vigilance") in the Reduta archive, library, prop room, and with the technical equipment, to help with the administration, to get to know the methods of organisational work (from Edward Zieliński, Reduta's administrative manager) and technical matters (under the direction of Gall). The physical training included three types of gymnastics: Swedish, Kosovan (inspired by the exercises from Apolinare Tarnawski's natural therapy centre) and those developed by Reduta itself. 
In the [Reduta] Preparations notebook, Osterwa designed a five-level grading scale:

\section{Final grades}

I. creative - imaginative

II. responsible $-[\mathrm{s} / \mathrm{he}]$ knows v.[ery] well

III. eager $-[\mathrm{s} / \mathrm{he}]$ knows well

IV. [s/he] studies - diligent

V. clueless - doesn't know.

These grades reflected the student's knowledge of the organisation of Okop and the Reduta Institute and Company, as well as their accomplishment in artistic and technical work and in touring. Every stage of education involved particular requirements. A junior student

who demonstrates sufficient attendance at the lectures and classes in Okop -

- knowledge of the Reduta principles, customs, and regulations

- efficiency of organisational work (vigilances)

- knowledge of Reduta's departments (arch.[ive], libr.[ary], collections, equipment)

- a good opinion from lecturers, teachers

can be admitted to public performance - in Okop and become a Senior Student ${ }^{62}$.

Seniors, in turn, in order to become candidates, had to pass "practically and satisfactorily" a touring internship. Junior students did not receive any pay, while seniors could get scholarships. Proper remuneration was only due to the candidates. On tour, however, the profit from ticket sales was split, and the students were also entitled to their share. As shown in [Reduta] Preparations, Osterwa was very meticulous in planning out the duties, regulations and rules concerning the students' participation in the tours, in which he got them involved right from the start from $1924^{63}$. It was a form of an obligatory internship, a practical test of their

${ }^{62}$ See J. Osterwa, Okop in the appendix.

${ }^{63}$ Reduta toured for fifteen years (1924-1939). An unusual phenomenon in the theatre life of the time, it was a systematic endeavour to present Polish drama in the whole Republic of Poland (and especially in the Eastern Borderlands). One of the most important artistic undertakings to this end was the series of open-air performances of The Constant Prince between 1926 and 1927, when Calderon/ Slowacki's drama was made available to half of Poland's population. In the first four touring seasons, Reduta gave over eighteen hundred performances in the smallest towns throughout Poland; between 1929 and 1932, the company visited over one hundred towns in the eastern- and westernmost part of the country, as well as in the north and south, presenting another thousand performances. Reduta's touring was a meant as a service to the society: popularising theatre, making valuable works available to the public, breaking with theatre elitism and reaching out to every spectator. It was the first endeavour on such scale in the history of Polish theatre. See D. Kosiński, W. Świątkowska, Teatr Reduta, [in:] Encyklopedia teatru polskiego (2019), http://encyklopediateatru.pl/teatry-i-zespoly/1383/teatr-reduta [accessed: June 23, 2020]. 
usefulness and skills. That is why the equipment of Okop, apart from a blackboard and a book collection, included items such as a geographical map of Poland, an administrative map, a railway map, and a railway timetable.

When touring, the students performed on stage (they were the second cast, for example in Jerzy Szaniawski's Murzynek, which toured in 1933) and interned in "technical, housekeeping, and administrative" affairs. They were assigned to particular organisational departments; they served as orderlies and stagehands, sold tickets and took care of the equipment. Bronisław Nycz recalled how on the 1925 tour he was responsible for the "postal department", i.e. sending out and collecting letters and parcels ${ }^{64}$, while Stanisław Hiż wrote about the tour of 1939: "Osterwa was extremely strict; he demanded a scrupulous and serious approach to duties. On tour, apart from one's stage role, everyone had some other function. Mine ... was to keep a chronicle" ${ }^{95}$. His colleague, in turn, measured and described all stages on which they played. It was a practical test of their commitment, diligence and a sense of belonging to the company. Osterwa put down in his notebook a speech to the Okop students:

You must realise that the trial of the tour is of utmost importance to you, as way of maturing in the service of Polish Art. -

If the conditions allow you - and you become engaged in the tour, remember that you must learn practically the whole touring organisation of Reduta. It is an important, and, let us be honest, a difficult course. It will be easy if you approach the performance of your tasks with the humility of patient monks, and the carrying out of your guardians' orders with the obedience of eager soldiers.

On the road, you are supposed not only to maintain the character of a model candidate, but also to develop this character. . .

First of all, there's the matter of learning the touring regulations. They must be followed on the road, even with some exaggeration.

From the company management's announcements you will learn about the staffing of organisational departments - you will take turns at them, doing shifts.

You must know by heart the inventory of equipment, your own and that which gets put under your care. Thus, you will know the inventory of artistic, stage, technical, organisational, railway, and household equipment....

On the road, you will have enough time for physical exercise, party games, educating yourselves through Reduta readings and for writing your theoretical essay at Okop - provided that you strictly follow the daily schedule ${ }^{66}$.

${ }^{64}$ See B. Nycz, Teatr czy uniwersytet?, [in:] O Zespole..., op. cit., pp. 195, 228.

${ }^{65}$ S. Hiż, Garść wspomnień Redutowca z lat 1937-1939, [in:] O Zespole ..., op. cit., p. 333.

66 J. Osterwa, Przygotowania [Redutowe], [in:] idem, Dzienniki wypraw 1938-1939, ed. A. Kruczyński, W. Świątkowska, Warszawa 2020 [in print]. 
Osterwa developed an hour-by-hour schedule for the members of Okop:

Until 9 am you may sleep.

From 9 till $10 \mathrm{am}$ - one hour for washing, (shaving), dressing, and the morning meal.

Until 10 am you should tidy up your beds and the whole carriage.

From 10 till 12 take care of the group's organisational matters: draw up reports etc.

From 12 till 2 p.m. do organ.[isational] errands outside the train - according to the group manager's or your guardians' instructions.

At 2 p.m. show up timely for lunch - at the designated venue, and take your assigned place at the table.

After dinner until 6 aft.[ernoon] you have the right to individual repose. You may read, write letters, nap, play chess etc.

At 5 p.m. Okop meeting, according to the sub-leader's instructions.

From 4 till 6 p.m. absolute silence must be kept in the carriage.

At 6 p.m. you will be preparing for the performance - in the carriage.

At 7 p.m. you are to be present at the place of the performance and prepare on site.

From 8 till 11 p.m. - performance.

From 11 p.m. till midnight daily report.

At 1 a.m. the light in the cars must go off. Silence. Sleep ${ }^{67}$.

Osterwa recommended that students see the historical sights and cultural attractions of particular towns; that they go sightseeing together, sharing their impressions with one another. They were also supposed to align their reading with the places visited and combine it with excursions: for example, Krzemieniec was the place to read Słowacki's Letters, Kraków - Wyspiański's Liberation and The Hamlet Study, and Norwid's Krakus, Lublin - Fredro's comedies, Vilnius - Forefathers' Eve. He also demanded that students avoid restaurants and cafés, as well as the cinema; drinking alcohol, whistling, and any noisy behaviour were prohibited.

Touring prepared the students for work in challenging conditions (they often played in places hardly fit for the purpose, or in the open air), taught them how to improvise and react to difficult situations, how to live together amicably (three months in one carriage!), how to cooperate and stay disciplined, but most importantly, it required a social commitment and made them see theatre work as a societal service and a mission ${ }^{68}$.

Compared to the Institute in the 1920s, in the 1930s Okop was run with a greater emphasis on systematisation and curriculum planning. Osterwa also paid more

${ }^{67}$ Ibidem.

${ }^{68}$ See W. Świątkowska, Koncepcje teatru społecznie zaangażowanego wedlug Juliusza Osterwy, „Pamiętnik Teatralny” 2018 no. 3, pp. 146-168, https://doi.org/10.36744/pt.423 [accessed: June 20, 2020]. 


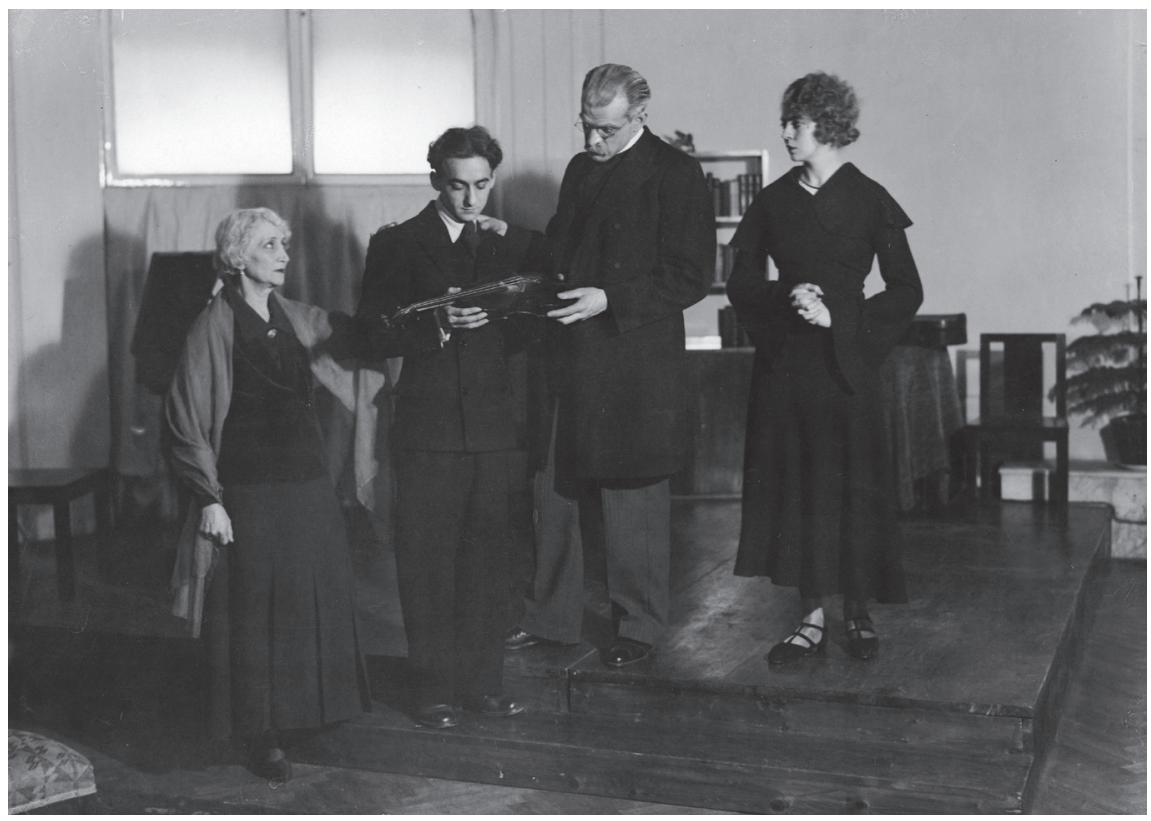

Rostand's The Man I Killed at the Reduta Institute in Warsaw, Helena Rolandowa, Roman Zawistowski, Kazimierz Brodzikowski and Nina Świerczewska, 1933, National Digital Archives

attention to discipline, drilling, and obedience. In the first years of operation, the Reduta school used to have an irregular class schedule, which gave students more freedom and space for educational experiments. Tadeusz Byrski, one of the first students, stressed that the Institute had no «teaching grid» whatsoever", and that many students were bothered by the "complete lack of academic discipline which is probably indispensable in a theatre-laboratory". "One actually witnessed an aversion to any kind of systematisation of experiences"69 - which had its advantages and disadvantages. In later years, following the hard lesson of the Vilnius period (when many members left and the company suffered disorganisation and malpractice, including instances of financial fraud), Osterwa emphasised the importance of regulations, charters, and precision in defining the scope of responsibilities and membership conditions. This was related to the general approach of "reorganising Reduta from the foundations" ", as he put it in a letter to Białkowski, and with writing down its "constitution", i.e. the principles and ideological premises. A trace of these plans can be found in Osterwa's wartime note in which he

69 T. Byrski, op. cit., pp. 176-177.

70 Osterwa's letter to T. Białkowski, 9 Oct. 1937, op. cit., p. 220. 
described how students dress or perform a given exercise on command - more like in the army than at school ${ }^{71}$. Listed among his requirements were: dedication, attachment, respect, self-denial (!), diligence in learning, zeal at work, vigilance in class, responsibility to the service, and exemplary, model behaviour ${ }^{72}$.

The archive material about Okop (published in the appendix) shows Osterwa's consistency in pursuing this direction. He wanted to control his students' leisure time: he forbade certain forms of entertainment and demanded continuous education and full dedication to studying and work. This was likely also connected with the desire to maintain a high morale among the students. Osterwa's predilection for ordering, regulating, and systematising things ${ }^{73}$ was manifest in his establishing a hierarchy at Okop (leader, deputy, secretary, junior student, senior student) and designing uniforms and badges. The curriculum was very precisely elaborated as well. Particular subjects were assigned to specialists in respective fields; the teaching staff were to become increasingly professionalised. In Okop, students were also involved in a greater number of tasks, which was due to the expansion of Reduta's activities in the 1930s. They took part in the initiatives of the School Theatre and the Radio Studio, as well as in poetry mornings organised in collaboration with the students of Polish philology at the University of Warsaw. Thus, a comparative analysis of the operational principles of the Reduta Institute and Okop confirms that while the comprehensiveness of education and the practical approach to training remained the most important aspects of Reduta's educational system, with time both theory and practice were taught in an increasingly systematic and calculated manner.

\section{THE ETHOS}

Zbigniew Osiński stressed that the Reduta Institute exhibited an almost monastic discipline ${ }^{74}$; the ideological and artistic programme was radical and the requirements high. The principles introduced by Osterwa in the Reduta company, at the Institute, in Okop, and on tours were inspired by monastic organisation; they were aimed at teaching humility and conscientiousness, and above all at ensuring that individuality would be subordinated to teamwork. Michał Orlicz wrote about "the gravity of work" and about "celebrating work at Reduta"75, and Zbigniew

${ }^{71}$ See J. Osterwa, Przez teatr - poza teatr, op. cit., pp. 300-312.

${ }^{72}$ Ibidem, p. 305.

${ }^{73}$ I discussed this obsession of sorts in W. Świątkowska, Ujarzmić Ananke, [in:] J. Osterwa, Dzienniki wypraw..., op. cit.

${ }^{74}$ Z. Osiński, Pamięć..., op. cit., p. 82.

75 M. Orlicz, op. cit., p. 293. 
Raszewski even mentioned "work fanaticism" "76. Ireneusz Guszpit noted that "The rigour of Reduta work and the sacrifices it required were compensated for by the voluntary nature of our choice and by the joyful sense of community" "77. This was Osterwa's way of turning a group of sometimes random people into a proper team, teaching them cooperation and co-responsibility. By strictly enforcing obligations and imposing rigid discipline, Osterwa did not so much educate actors as ideologically committed theatre activists, or even social activists. Byrski stressed that Reduta's main "concept in theatre education" was "an actor comprehensively prepared for the profession: for both the work itself and for civic duties" ${ }^{\text {"78. Simi- }}$ larly, Sznaper-Zakrzewska wrote: "Reduta was a great school for the art of acting, and at the same time a great school for social life, a rich, fully-fledged stream of work" "79, and Małkowska declared that Osterwa above all "insisted that if someone decided to work at the theatre, it should be the most important matter in his or her life" $" 80$.

Such were the maximalist demands of the Reduta school - theatre was to constitute the most important thing or cause in one's life. Commemorating Osterwa after his death, Aleksander Zelwerowicz declared that he was "a downright brilliant educator . ..., and [that] the Reduta Institute, for many years to come, will play a great role in the history of Polish theatre and in shaping the professional ethics of the Polish actor" $"$. He was not mistaken. And even more importantly, the holistic and maximalist approach to the performing arts, introduced in Reduta and perpetuated by means of innovative teaching methods, has played a decisive role in the process of raising the social status of the acting profession in Poland.

Translated by Zofia Ziemann

${ }^{76}$ Z. Raszewski, Krótka historia teatru polskiego, Warszawa 1977, p. 201.

77 I. Guszpit, Wstepp, op. cit., p. 52.

78 T. Byrski, op. cit., p. 183.

79 S. Sznaper-Zakrzewska, op. cit., p. 348.

${ }^{80}$ H. Małkowska, op. cit., p. 89.

${ }^{81}$ A. Zelwerowicz, O sztuce teatralnej, ed. B. Osterloff, Wrocław 1993, pp. 189-191. 


\begin{abstract}
ANEKS
Fragment dotyczący organizacji Okopu pochodzi z zeszytu Przygotowania [Redutowe $]^{82}$ prowadzonego przez Juliusza Osterwę pomiędzy czerwcem a wrześniem 1939. Raptularz jest przechowywany w zbiorach Muzeum Teatralnego w Warszawie, w sławnej walizce Osterwowej przekazanej przez Marię Osterwę-Czekaj w 1997 (sygn. MT/IX/480/2). Do druku zostały wybrane karty 12, 14-27 rękopisu, gdyż stanowią one całostkę poświęconą szkole Reduty. Kończący fragment wpis: „Zwyczajowy plan zajęć Okopu w objeździe” można datować dzięki notatce w dzienniku z Wyprawy z „Powrotem Przełęckiego”, w której Osterwa pod datą 24 czerwca 1939 (podczas postoju w Skarżysku) zapisał: „Ułożyłem rano: «Zwyczajowy plan zajęć Okopu w objeździe» i «Obyczajowe zwroty redutowe w obcowaniu wzajemnym i podczas współpracy»" ${ }^{" 3}$. Można zatem przypuszczać, że publikowane tu materiały dotyczące organizacji szkoły powstały w czerwcu 1939. Wcześniejsze karty Przygotowań [Redutowych] zawierają bardzo skrótowe i schematyczne notatki z planami repertuarowymi Reduty, obsadami sztuk, kalendarzem premier, spisy nazwisk redutowców, przyjaciół Reduty, honorowych członków i zwolenników, wyliczenia dramatów. Są to w dużej mierze zapisy szkicowe - inwentarze wyliczenia - częściowo niekompletne, notowane przeważnie ołówkiem i pozostawione do rozwinięcia. Zajmują one trzynaście pierwszych stron zeszytu. Dalej Osterwa planuje organizację objazdów Reduty: robi spisy sprzętów potrzebnych w objeździe, opracowuje repertuar i obsady, notuje zasady wynagrodzeń, ustala reguły obowiązujące w wagonach, wyznacza obowiązki uczestników, rozdysponowuje zadania, projektuje formularze, w końcu planuje marszruty i wypisuje miasta. Ta część (k. 26-64) została przygotowana do druku w tomie Dzienniki wypraw 1938-1939, w którym znajdują się dzienniki Osterwy ze zbiorów Muzeum Teatralnego: Podróż do Ceuty (1939) oraz dwie relacje z objazdów - z dramatem Stefana Żeromskiego Uciekta mi przepióreczka (1938) oraz z Powrotem Przetęckiego Jerzego Zawieyskiego (1939). Obszerny fragment Przygotowań [Redutowych] został decyzją redaktorów włączony do wydania dzienników wypraw jako immanentna cząstka, która może dać czytelnikom wyobrażenie o organizacyjnej stronie objazdów. W tomie relacji z tras nie znalazł się jednak publikowany tutaj fragment dotyczący organizacji uczelni Reduty. Całostka ta wydaje się skończona i interesująca, można ją czytać w kontekście dalszej części Przygotowań [Redutowych] drukowanych w książce. Przygotowania [Redutowe] to de facto dwie osobne całostki: organizacja Okopu oraz organizacja objazdów.

Okop to nazwa uczelni W.I.R. (Warszawskiego Instytutu Reduty) obowiązująca od października 1937, wcześniej uczelnia ta funkcjonowała jako Instytut Reduty. „Młodych adeptów sztuki postanowiono kształcić metodycznie w kierunku scenicznym. Instytut teatralny przekształcił się w szkołę pod
\end{abstract}

82 Tytuł „Przygotowania” pochodzi od Osterwy, natomiast słowo „Redutowe” dopisała Matylda Osterwina, dlatego umieszczam je w nawiasie kwadratowym.

83 J. Osterwa, Dzienniki wypraw 1938-1939, red. A. Kruczyński, W. Świątkowska, Warszawa 2020 [w druku]. 
kierunkiem pani Gallowej. Szkołę tę ochrzczono mianem Okop" ${ }^{44}$ - notuje jeden z adeptów; Okop to późniejsza nazwa Instytutu - dodaje druga ${ }^{85}$ spośród uczestników; „Okop był szkołą młodych redutowców" ${ }^{" 86}$ - uzupełnia trzeci wychowanek.

Notatki Osterwy na temat organizacji Okopu to plan przygotowań do nowego roku szkolnego, który miał zacząć się we wrześniu 1939. Osterwa ustala program nauczania, rozdziela wykłady, rozpisuje rok szkolny i harmonogram zajęć. Określa obowiązki ucznia, zasady przyjmowania do Okopu, wymagania wstępne wobec kandydatów, ćwiczenia praktyczne, praktyki objazdowe, kryteria oceny. Rozważa kwestie finansowe, stypendia i wynagrodzenia. W końcu omawia strój uczniów (szaty, płaszcze, odznaki okopowe, napierśniki, chusty, opaski) i projektuje legitymacje.

Ten materiał jest cennym uzupełnieniem wiedzy na temat redutowego systemu szkolnictwa. Uzmysławia, że Osterwa poważnie podchodził do metod kształcenia adeptów, a Okop był profesjonalną „uczelnią ze zdecydowanym programem i regulaminem"87. Osterwa doskonale zdawał sobie sprawę, jak ważne jest edukowanie kolejnych pokoleń. Jak myślał o przyszłości, uświadamia beletryzowany zapis etapów edukacji, który sformułował już podczas okupacji (w listopadzie 1940). Na przykładzie historii Janiny Smużanki (fikcyjnej córki Smugoniów z dramatu Uciekła mi przepióreczka Stefana Żeromskiego), która zapisuje się na zajęcia w Okopie, Osterwa kreśli obraz nowoczesnego szkolnictwa teatralnego ${ }^{88}$. Cały pomysł trafnie charakteryzują słowa Adama Mieczysława Sznapera, odwołujące się do militarnego nazewnictwa wymyślonego przez Osterwę: „Reduta była fortecą i przybytkiem Muzy, Okop był jej przedmurzem" ${ }^{\text {99 }}$. Każdej reducie potrzebny jest okop, by mogła sprawnie funkcjonować i pełnić swe zadania.

Pisowni nie uwspółcześniano, zachowano układ graficzny tekstu, oczywiste błędy pióra i interpunkcję poprawiono bez zaznaczania; uzupełnienia edytorskie pojawiają się w nawiasach kwadratowych.

\section{JULIUSZ OSTERWA OKOP}

\section{Zwyczaje:}

Ażeby wstąpić do Okopu, należy się zapisać na członka nadzwyczajnego Tow.[arzystwa] Zespołu Reduty do t.[ak] z.[wanego] grona „Przyjaciół Reduty”

Przyjaciel Reduty ma prawo przebywać w Okopie w charakterze Gościa - za zgodą [kierownika Instytutu Reduty - przekreślone] Nacz.[elnego] Kier.[ownictwa] R.[eduty]

${ }^{84}$ A. M. Sznaper, Pierwsze kroki, [w:] O Zespole Reduty 1919-1939. Wspomnienia, Warszawa 1970, s. 325.

${ }^{85}$ „Grupa pierwszych wychowanków Instytutu, późniejszego Okopu, była nieliczna. Dopiero z biegiem lat zwiększały się ich szeregi”, A. Wójcikiewicz-Rumlowa, O ostatnim Instytucie Reduty, [w:] ibidem, s. 339.

${ }^{86}$ S. Hiż, Garść wspomnień Redutowca z lat 1937-1939, [w:] ibidem, s. 335.

${ }^{87}$ List Osterwy do T. Białkowskiego z 9 X 1937, [w:] Listy Juliusza Osterwy, red. E. Krasiński, Warszawa 1968, s. 220.

${ }^{88}$ J. Osterwa, Przez teatr - poza teatr, wybór i oprac. I. Guszpit, D. Kosiński, Kraków 2004, s. $300-312$.

${ }^{89}$ A. M. Sznaper, op. cit., s. 325. 
Zapoznaje się z Opiekunem Okopu, który go zapoznaje z Przodownikiem, ten z VI-ką ${ }^{90}$

VI-ka zapoznaje z wszystkimi członkami Okopu. -

Gość ma prawo przybywać i przebywać w Okopie, kiedy zechce i jak długo zechce.-

Instrukcja dla Opiekuna Okopu i VI-ki

Sprawdzić opinię Zarządu Zespołu Reduty

Gość może zostać stałym Słuchaczem Okopu na wniosek VI-ki (Przodownika), o ile otrzyma na to zezwolenie Opiekuna Okopu.

Słuchacza obowiązuje obecność na wykładach. W ćwiczeniach może brać udział za zgodą VI-ki (Przodownika) i Opiekuna Okopu.

Słuchacz będzie przyjęty do Okopu na próbę w charakterze Ucznia I-go stopnia, $\underline{\text { młod- }}$ szego -

I. jeśli poda dokładne odpowiedzi na pytania dotyczące osobistych spraw według załączonego kwestionariusza

II. jeśli się wykaże znajomością:

A.

a) Statutu Tow.[arzystwa] Zespołu Reduty

b) Regulaminu Inst.[ytutu] R.[eduty]

c) Regulaminu Okopu R.[eduty]

B. lektury redutowej:

1. Listy Słowackiego

2. Promethidion Norwida

3. Studium o Hamlecie

III. jeśli sobie sprawi:

a) płaszcz do pracy

b) strój do ćwiczeń ruchowych

* Sprawdzić odpowiedzi na pytania:

1. imię i nazwisko

2. wiek - data urodz.[enia]

3. wyznanie

4. miejsce urodzenia

90 Szóstka to określenie zbiorowego ciała kierownictwa - zespołu administracyjnego szkoły - działającego pod kierunkiem Opiekuna Okopu. Por. dalsze zapiski. 
5. wykształcenie

6. umiejętności artyst.[yczne]

7. stanowisko socjalne

8. intencja wstąpienia do R.[eduty]

9. położenie materialne

10. adres

Zbadać warunki zewnętrzne:

1. zdrowie

2. wzrost, budowa, rysy

3. głos, siła, brzmienie, oddech

4. wymowa

5. słuch, poczucie rytmu

6. spojrzenie

7. ruchy

Zbadać wiedzę redutową: regulaminy wiedzę lektury redutowej

Uczeń młodszy

obowiązany jest: poddać się wstępnemu badaniu

* przybywać punktualnie na wykłady i ćwiczenia

* wypełniać polecenia Przodownika i Op.[iekuna] Okopu

* co tydzień wpłacać dobrowolnie zaofiarowaną składkę

* używać słownictwo Reduty

Wybadać stosunek do: religii, wiary

do rodziny, ludzi

przekonania polityczne

stosunek do przyrody

$$
\begin{aligned}
& \text { do otoczenia żywego } \\
& \text { do kraju - ojczyzny }
\end{aligned}
$$

Zbadać inteligencję

zdolności

zapał

charakter

Zbadać wiadomości

historii powsz.[echnej] i polskiej

historii literatury

o sztuce

o malarstwie, rzeźbie 
o muzyce, śpiewie

o tańcu

o literaturze

o teatrze

o scenie

o Reducie

Wykłady dla uczniów

+ Statut Reduty (Jeżewska ${ }^{91}$, Mysłakowska ${ }^{92}$ )

+ Regulamin (zasady) R.[eduty] (Mysłakowska)

Organizacja I.[nstytutu] R.[eduty] (Mysłakowska, Zieliński ${ }^{93}$ )

Regulamin Okopu (Gallowa $\left.{ }^{94}\right)$

+ Słownictwo R.[eduty] (J. O. ${ }^{95}$, Przodownik, Łuczyński ${ }^{96}$ )

Administracja (Przod.[ownik])

Sekretariat

Skarbnikostwo (księgowość - księgowy)

Sprawy objazdowe (Bąbolski ${ }^{97}$ )

Język polski (Jeżewska, Kochanowicz ${ }^{98}$ ) Literat.[ura] dram.[atyczna] (Jeżewska)

Gramatyka, stylistyka, prozodia Literat.[ura] pol.[ska]

${ }^{91}$ Kazimiera Jeżewska z d. Zwierzyńska (1902-1979), kierowniczka literacka. Ukończyła Uniwersytet Warszawski. Od 1931 współpracowała z warszawskim Instytutem Reduty jako kierowniczka literacka oraz kierowniczka archiwum i biblioteki. Była autorką tekstów i adaptacji scenicznych dla Teatru Szkolnego Reduty oraz sekretarzem Kapituły Reduty.

92 Zofia Mysłakowska z d. Braun (1896-1957), aktorka i reżyserka, związana z Redutą w latach 1919-1924, 1925-1928, 1932-1939, 1946-1947. W Instytucie Reduty prowadziła ćwiczenia sceniczne. Osterwa zaliczał ją do grupy „redutowców kapitulnych”.

${ }_{93}$ Edward Zieliński (1897-1958) w latach 1925-1929 był w zarządzie Reduty w Wilnie, w 19291930 był dyrektorem działu administracyjno-gospodarczego i dyrektorem administracyjnym w okresie 1931-1939, 1946-1947.

94 Halina Gallowa z d. Kacicka (1890-1974), aktorka, reżyserka i pedagog, żona Iwona Galla, z którym dołączyła w 1923 do zespołu Reduty. Z Redutą była związana w latach 1923-1930, 19381939. Od 1927 praktycznie prowadziła Instytut Reduty, wykładając w nim do wybuchu II wojny światowej (była specjalistką od nauki dykcji i recytacji). Zaliczana była przez Osterwę do „redutowców kapitulnych" i najwierniejszych sojuszników.

95 Juliusz Osterwa.

96 Tadeusz Łuczyński, właśc. Mroczkowski (ur. 1906), aktor, z Instytutem Reduty związany w latach 1932-1939 (objazdy).

${ }^{97}$ Eugeniusz Bąbolski (1894-1965) pracował w Reducie od 1926 do wybuchu II wojny światowej, administrator Reduty w Grodnie i Wilnie. Zaufany współpracownik Osterwy, który często powierzał mu kierownictwo redutowych objazdów.

98 Jan Kochanowicz (1879-1969), aktor, reżyser, działacz teatralny i społeczny. Występował w Reducie w latach 1919-1924, potem przeszedł do zespołu Teatru im. Bogusławskiego. Ponownie współpracował z Instytutem Reduty w latach 1938-1939. 
Fonetyka

Geografia Polski

Historia (Jeżewska)

Kultura

Teatr polski (Świerczewski ${ }^{99}$ )

Scena polska

ZASP (Kossowski ${ }^{100}$ )
Literat.[ura] dram.[atyczna] pol.[ska]

Fredro

Słowacki (Jeżewska)

Mickiewicz

Krasiński

Norwid

Wyspiański

o zachowaniu się...

o sposobie spożywania i picia

o ubieraniu się

Wykłady spisać - protokołować

1) egz.[emplarz] dla archiwum R.[eduty]

2) dla kierownictwa Okopu

3) dla archiwum Okopu

4) do przejrzenia, czytania

\section{Ćwiczenia dla Okopu}

Ćwiczenia oddechowe (Przodownik, ks. Wilczewski ${ }^{101}$ )

głosu (J. O., Przodownik)

śpiewu (Rutkowski ${ }^{102}$ )

99 Eugeniusz Świerczewski (1894-1944), dyrektor, kierownik literacki teatru, recenzent i krytyk teatralny, thumacz. W Reducie w latach 1922-1923 pełnił funkcję sekretarza, potem sekretarza literackiego (sformułował dla prasy podstawy ideologiczne i program artystyczny teatru w artykule Redu$t a$, ,Scena Polska” 1922 nr 3). W Instytucie Reduty wykładał historię teatru (1922-1924). W okresie 1932-1933 był kierownikiem literackim Instytutu Reduty i redaktorem „Wiadomości Redutowych”. W 1944 został powieszony z wyroku AK jako agent gestapo.

100 Jerzy Kossowski (1889-1969), aktor, reżyser, kierownik artystyczny teatru, pisarz i thumacz. W latach 1925-1927 był w zarządzie Reduty wileńskiej (wspólnie z Edwardem Zielińskim), w sezonie 1926/27 pełnił funkcje kierownika administracyjnego i kierownika „grupy grodzieńskiej”. Jako aktor występował w Reducie w latach 1924-1927, 1936 (Teatr Radiowy, Wesele).

${ }^{101}$ Ks. Stanisław Wilczewski (1886-1980), logopeda, kaznodzieja. Ukończył studia z fonetyki eksperymentalnej i filologii na Uniwersytecie w Hamburgu oraz w Państwowym Laboratorium Fonetycznym pod kierunkiem prof. G. Panconcelli-Calzii, zakończone w 1921 doktoratem. Specjalizował się w zakresie fizjologii wytwarzania głosu oraz leczenia zaburzeń głosu i mowy. W 1927 założył w Katowicach Instytut Fonetyczny - Poradnię Logopedyczną. Wykładał fonetykę pastoralną w seminariach duchownych. W 1929 jako jeden z pierwszych księży głosił kazania w Polskim Radiu. Był członkiem Polskiego i Międzynarodowego Towarzystwa Logopedycznego.

102 Bronisław Rutkowski (1896-1964), muzyk, pedagog, kierownik muzyczny teatru. Współpracował jako dyrygent, chórmistrz i kompozytor z Leonem Schillerem przy jego widowiskach muzycznych wystawianych w Reducie: Pastorałka (1922), Wielkanoc (1923) i Nowy Don Kiszot (1923). Związany 


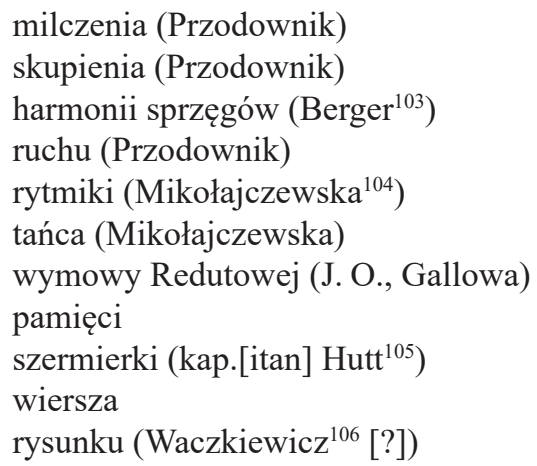

Teorię spisać, jak wykłady.

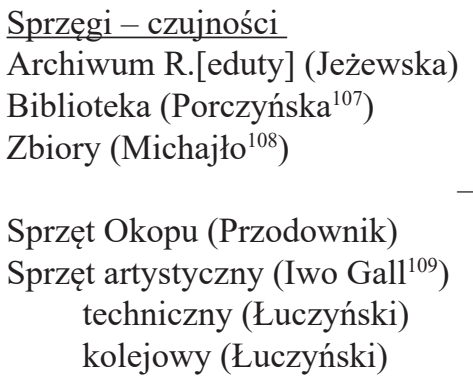

z Redutą w latach 1922-1925, 1933-1934, 1938-1939. W Instytucie Reduty prowadził zajęcia z umuzykalnienia, solfeżu i lekcje śpiewu. W latach 1923-1925 był kierownikiem wokalnym Instytutu (wraz z Karoliną Pietraszewską).

${ }^{103}$ Ludwik Berger (1911-1943), aktor, reżyser. Od 1930 występował w przedstawieniach objazdowego zespołu Reduty. Od 1931 był słuchaczem Instytutu Reduty w Warszawie, potem sam prowadził zajęcia dla młodszych kolegów (kontakt z partnerami) i został jednym z opiekunów Okopu. Był również organizatorem przedstawień szkolnych (do 1939). Podczas drugiej wojny światowej organizował wieczory recytatorskie i przedstawienia konspiracyjne. Był działaczem harcerskim. Zginął w walce z niemiecką żandarmerią w okupowanej Warszawie.

104 Zofia Mikołajczewska (1908-1984), tancerka, choreograf. Współpracowała z Instytutem Reduty w latach 1936-1939, w Okopie opracowywała choreografię i prowadziła zajęcia z ruchu scenicznego.

${ }^{105}$ Kpt. Wiktor Hutt (brak danych), pedagog gimnastyki i szermierki w Instytucie Reduty 1924-1925.

106 Być może pomyłka Osterwy i chodzi o Tadeusza Waczkowskiego (1919-1981), aktora, w Instytucie Reduty w latach 1936-1939 (Teatr Szkolny).

${ }^{107}$ Helena Maria Porczyńska (1904-1984), polonistka, bibliotekarka w Reducie wileńskiej (1924-1929).

108 Bolesław Michajło (ur. ? - 1944, zamordowany na Pawiaku) pracował w Reducie w pracowni perukarskiej (1929-1930), w objazdach (1931) i w administracji (jako opiekun mienia) 1932-1939.

109 Iwo Gall (1890-1959), scenograf, reżyser, dyrektor teatru. W 1923 dołączył wraz z żoną do Reduty; pracował w niej w latach 1923-1930, 1934, 1936, 1938-1939 jako scenograf, reżyser i kierownik artystyczno-techniczny, czuwający nad całokształtem spraw plastycznych (projektował stroje robocze, wystrój wnętrz teatru). W Instytucie Reduty wykładał historię sztuki i malarstwo, był także kierownikiem archiwum i biblioteki Instytutu. 
Czujność zewnętrzna (Przodownik) administracyjna (Przodownik)

Czujność wewnętrzna (Przodownik)

Metody artystycznej pracy (J. O.) organizacyjnej (E. Zieliński) technicznej (Gall, Łuczyński)

\section{Sprzęgi}

z malarstwem poprzez wystawy (Lorentz ${ }^{110}$, Tow.[arzystwo] Zach.[ęty] ${ }^{111}$ )

z muzyką poprzez koncerty (Gołębiowski ${ }^{112}$ )

z kinem (Buchwaldowa ${ }^{113}$ )

$\mathrm{z}$ radiem (Gallowa)

$\mathrm{z}$ scenami i teatrem

\section{Uczeń młodszy}

\section{$\underline{\text { Stopnie dojrzewania }}$}

który się wykaże odpowiednią ilością obecności na wykładach i ćwiczeniach w Okopie - znajomością zasad, zwyczajów, regulaminów Redutowych

- wydajnością pracy organizacyjnej (czujności)

- znajomością działów Reduty (arch.[iwum], bibli.[oteka], zbiory, sprzęty)

- dobrą opinią wykładowców, nauczycieli

może być dopuszczony do pokazu publicznego - Okopowego

i zostać Uczniem Starszym.

Decyduje o tem VI-ka i Opiekun Okopu.

Uczeń starszy, który przejdzie praktycznie i zadowalająco staż objazdowy - zostanie na wniosek Op.[iekuna] Okopu i Dyr.[ekcji] Instytutu [kandydatem Reduty - skreślone] Przodownikiem Okopu.

[Kandydat Reduty - skreślone] Przodownik Okopu może zostać redutowcem, czyli zwyczajnym członkiem Tow.[arzystwa] Zespołu Reduty na wniosek Dyr.[ekcji] Instytutu - zatwierdzony przez Zarząd Z.[espołu] R.[eduty], o ile wykaże się dokładną znajomo-

110 Stanisław Lorentz (1899-1991), historyk sztuki, muzeolog, dyrektor Muzeum Narodowego w Warszawie (1935-1982), kierował Katedrą Historii Sztuki na Uniwersytecie Warszawskim.

111 Towarzystwo Zachęty Sztuk Pięknych powołane w Warszawie w 1860. W 1900 powstał gmach Towarzystwa projektu Stefana Szyllera, gdzie mieści się dziś Zachęta Narodowa Galeria Sztuki.

112 Leon Gołębiowski (1914-1954), aktor, w latach 1938-1939 w Instytucie Reduty (Okop).

113 Maria Buchwaldowa z d. Kryszkiewicz (1910-2003), związana z Instytutem Reduty w latach 1934-1939: uczestniczyła w objazdach, występowała w Teatrze Szkolnym, współpracowała ze Studiem Radiowym, była jedną z opiekunek w Okopie. 
ścią pełnej organizacji R.[eduty] (odcinek Pok.[azów] Szk.[olnych], Pok.[azów] Miejsc. [owych] i Pok.[azów] Obj.[azdowych]), zasad ideowych, metod pracy art.[ystycznej], propagandowej, administracyjnej i techn.[icznej].

Obyczajowe zwroty redutowe w obcowaniu wzajemnym i przy współpracy

- W zasadzie, wśród Zespołu Reduty - w obcowaniu towarzyskim, koleżeńskim i przy współpracy redutowej - unika się używania nazwisk, stosuje się je tylko do „Przyjaciół Reduty” - nawet, kiedy biorą udział w życiu Reduty, jako goście lub słuchacze.

- Redutowcy starsi przemawiają do siebie po imieniu (redutowym), do młodszych redutowców i kandydatów zwracają się „per kolego”, dodając imię zdrobniałe; do uczniów starszych ,per pan” z imieniem zdrobniałym, do ucz.[niów] mł.[odszych] „per pan” z imieniem chrzestnym. Do „ochotników” „per pan” z nazwiskiem, do współpracowników bliższych ,per pan” z im.[ieniem] chrzestnym.

Uczniowie młodsi ze sobą: kolego + imię zdrobniałe do starszych: kolego + imię chrzestne do kand.[ydatów] i red.[utowców]: panie + imię chrzestne

Uczniowie starsi do młodszych: kolego + imię chrzestne ze sobą: kolego + imię zdrobniałe do kand.[ydatów] i red.[utowców]: panie + imię zdrobniałe

Do gości i słuchaczów: pan + nazwisko lub imię chrzestne.

- Gość i słuchacz opłacają składki wprost do Tow.[arzystwa] Zespołu R.[eduty]

- Uczniowie opłacają składki według umowy z VI-ką

- Uczniowie młodsi nie otrzymują żadnych wynagrodzeń

- Uczniowie starsi mogą otrzymywać stypendialne honorarium

- [Kandydaci Reduty - skreślone] Przodownicy Okopu mają prawo do punktów według „klucza procentowego” - który dotyczy pracowników redutowych.

Uczniowie Okopu w objeździe są nadal uważani za uczniów podporządkowanych Opiekunowi Artystycznemu i są obowiązani do dalszych ćwiczeń organizacyjnych.

Pobierają wynagrodzenia według „klucza procentowego” (jako uczniowie młodsi i starsi lub kandydaci).

Na wniosek Opiekuna Art.[ystycznego,] Kierownika grupy i Kier.[ownika] Pok.[azów] Obj.[azdowych] mogą otrzymać specjalne wynagrodz.[enie] z kasy Tow.[arzystwa] Zesp.[ołu] R.[eduty]. 
Stopnie Okopowe są zależne od:

znajomości organizacji Okopu

organizacji Instytutu

organizacji Zespołu Reduty

i wydajności pracy artystycznej

pracy technicznej

pracy objazdowej (kolejowej)

$\underline{\text { Stopnie świadectw }}$

I. twórczy - pomysłowy

II. odpowiedzialny - zna b.[ardzo] dobrze

III. gorliwy - zna dobrze

IV. uczy się - pilny

V. nie wyznaje się - nie zna

* Należy prowadzić dokładną ewidencję uczniów

* Legitymacje

Kierownictwo Inst.[ytutu] Reduty zaświadcza

iż p. X.Y.

jest członkiem uczelni Zespołu Reduty

*

(przebywa w Instytucie Reduty)

w charakterze... ucznia młodszego

- Zaświadczenie -

W imieniu Kierownictwa Warsz.[awskiego] Inst.[ytutu] Reduty zaświadcza się na życzenie p. X.Y.

że p. X.Y.

przebywał w Inst.[ytucie] Reduty

od dnia -

w charakterze ,ucznia młodszego"-

\section{Opiekun Uczelni W.I.R}

- odznaki Okopowe

- napierśniki podczas obrad + chusty

- opaski służbowe 
Wstepne wykłady:

* Regulaminy, Statut Inst.[ytutu], Okop[u]

* Literatura: Listy Słow.[ackiego], Promethidion, Studium o Hamlecie

* Słownictwo Reduty

* Geografia Polski

* Historia Polski

* Historia lit.[eratury] dram.[atycznej]

* Sprawy objazdowe

Ćwiczenia wymowy redutowej

Gimn.[astyka], rytm.[ika], tańce

Śpiew

Milczenie, symetryczność

Pamięć

Czujności

Poznanie Arch.[iwum]

Bibl.[ioteki]

Zbiorów

Sprzętu

Sekretariat

* Sprzet Okopu *

* Mapa geogr.[aficzna] Polski

administr.[acyjna]

kolejowa

* tablica

* biblioteczka

* rozkład jazdy kolejowy

napierśniki

opaski służbowe

płaszcze - o[d]znaki Okopowe

szaty

\section{Tworzywo Okopu}

+ Oda do młodości, Veni Creator

+ Psalmy Gomółki, Bogurodzica

+ Polonez, krakowiak, mazur, kujawiak

+ Śnieg, Pierścień Wielkiej Damy, Przepióreczka

Balladyna, Lilla Weneda, X. Niezłomny

+ Maliny Chodźki 
+ Misterium ${ }^{114}$ Stryjeńskiej

+ Misterium nocy majowej Morstina

+ Wanda Norwida, Krakus

\section{Ćwiczenia Okopowe}

* milczenia, skupienia

* symetryczności

* karuzel, (Lajkonik), konna jazda

* gimnastyka - „,szwedzka” ${ }^{115}$, kosowska ${ }^{116}$, redutowa

* oddechy

* mimika

\section{- Kultura artystyczna -}

Treść śpiewna:

1. Psalmy Gomółki

2. Bogurodzica

3. kolęda z Złotej Czaszki

4. Święty Boże

5. kolędy

6. Wesoly nam dzień

7. śpiewy gregoriańskie

8. pieśni do Ks.[ięcia] Niezłomnego

9. chór Lilli Wenedy

10. Wesele
Treść malarska:

1. Matejko

2. Grottger

3. Ruszczyc

4. Drabik

5. Malczewski

6. Mehoffer
Treść taneczna:

1. Polonez

2. Krakowiak

3. Mazur

4. Kujawiak - oberek

5. Taniec góralski

6. Lajkonik

walc

trojak
Treść muzyczna:

Chopin: Etiudy

Walce

Imprompta

Nocturny

Sonata h-moll

Polonezy

Polonezy Ogińskiego

Kujawiaki (płyty)

114 Pascha. Pieśń wielkanocna. Widowisko religijne w VI obrazach - misterium, autorski scenariusz Zofii Stryjeńskiej (rkps w zbiorach Biblioteki Jagiellońskiej).

115 Gimnastyka szwedzka - rodzaj ćwiczeń gimnastycznych zapoczątkowanych przez Pera Henrika Linga i jego syn Hjalmara Linga na początku XIX w. w Szwecji. Charakteryzowała się powolnymi ruchami o ściśle określonych kierunkach.

116 Od Kosowa - miasteczka w Karpatach Wsch., w powiecie stanisławowskim, obecnie na Ukrainie. W latach 1891-1939 działało tam sanatorium prowadzone przez doktora Apolinarego Tarnawskiego, pioniera i propagatora medycyny naturalnej, do którego Osterwa regularnie jeździł na leczenie i wypoczynek. 
taniec solowy Muz.[yka] Marczewskiego ${ }^{117}$ (do Ks.[ięcia] Niezt.[omnego]) taniec zespołowy

\section{Program prac w Okopie}

Od 15 | 25 sierp.[nia]: formalności

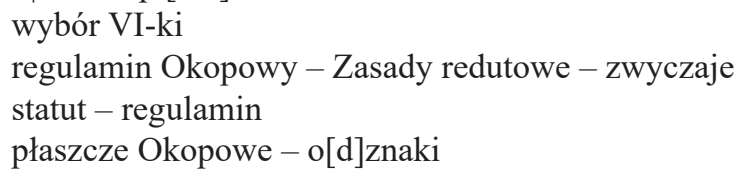

Od 1 | 29 wrześ.[nia]: Ćwiczenia

pon.: ruch (Mikołajczewska)

wtor.: głos (Rączkowski ${ }^{121}$ )

środa: wymowa (Gallowa)

czwartek: ruch

piątek: głos, milczenie

sobota: wymowa

strój gimn.[astyczny] - lektura Okopowa

117 Lucjan Marczewski (1879-1935), kompozytor i pedagog muzyczny; w latach 1912-1914 prowadził w Warszawie własne liceum muzyczne; autor muzyki do przedstawień teatralnych, utworów fortepianowych, pieśni chóralnych i solowych. Skomponował muzykę do Księcia Niezłomnego w reżyserii Osterwy, wystawionego w Teatrze Polskim w Warszawie (prem. 13 IX 1918).

118 Eugeniusz Dziewulski (1888-1978), dyrygent, kierownik muzyczny i dyrektor teatru, reżyser, scenograf. Kierownik muzyczny i pedagog w Instytucie Reduty w latach 1924-1929. Komponował muzykę do większości przedstawień Reduty w okresie wileńskim i dyrygował jej wykonaniem (m.in. do Wesela, Wyzwolenia, Nowego Don Kiszota, Ptaka, Snu, Betleem Ostrobramskiego, Erosa i Psyche, Księcia Niezłomnego).

119 Michał Kondracki (1902-1984), kompozytor, pedagog, publicysta muzyczny. Był współorganizatorem i wiceprezesem Polskiego Towarzystwa Muzyki Współczesnej, należał do czołówki polskiej awangardy muzycznej w okresie międzywojnia. Zbierał także folklor muzyczny Huculszczyzny, Podhala i Żywiecczyzny.

${ }^{120}$ Jan Karol Gall (1856-1912), kompozytor, dyrygent, pedagog i krytyk muzyczny, ojciec Iwona Galla. Wykładał w konserwatoriach w Krakowie i Wrocławiu, od 1896 dyrygent chóru Echo-Macierz we Lwowie. Autor licznych pieśni solowych i chóralnych oraz opracowań pieśni ludowych.

${ }^{121}$ Feliks Rączkowski (1906-1989), pedagog, organista, kompozytor. Uczeń Bronisława Rutkowskiego, od 1937 wykładowca w warszawskim konserwatorium. Był organistą w kościele Świętego Krzyża w Warszawie i autorem licznych opracowań pieśni kościelnych. 
Od 15 wrześ.[nia] wykłady:

pon.: kultura hist.[orii] art.[ystycznej] (ogólna) (Gall)

wtor:: $\quad$ teatralna (Orlicz ${ }^{122}$, Świerczewski)

środ: $\quad$ literacka (Jeżewska)

czw: $\quad$ muzyczna (Gołembiowski ${ }^{123}$ )

piąt: taneczna (Mikołajcz.[ewska])

sob: mal.[arska], rzeźb.[iarska] (Gall)

wycieczki (Lazienki), kino, odczyty, koncerty, wystawy

Od 1 paźdz.[iernika]

- ćwiczenia pamięci

- analizy

Od 15 paźdz.[iernika] - metody pracy artyst.[ycznej]

Od 1 listop.[ada] - sytuacyjność

Od 15 listop.[ada] - Spełnia.

Posunięcia w śpiewie

* głos, oddechy

* nuty

* treść: $5,3,4,8-1,2,6,7$

$9,10^{124}$

Posunięcia w ruchu

* ruch

* symetryczność

* polonez

* kujawiak

Posunięcia pamięci

Oda do mtodości, Dialogi

Veni Creator

Zespół Okopu:

- Opiekun Okopu

122 Michał Orlicz, właśc. Jerzy Michał Löwenstark, Lövenstarck (1893-1970), dyrektor, kierownik literacki i artystyczny teatru, reżyser, recenzent; redaktor naczelny „Sceny Polskiej” (1922-1924). Kierownik literacki Reduty w latach 1926-1929 (w sezonie 1928/29 wspólnie z Tadeuszem Łopalewskim). Wygłaszał prelekcje przed plenerowymi pokazami Księcia Niezłomnego (1927). Autor monografii Polski teatr współczesny. Próba syntezy (Warszawa 1935), której obszerne fragmenty poświęcone są działalności Reduty.

${ }^{123}$ Leon Gołębiowski (1914-1954), aktor, w Instytucie Reduty w latach 1938-1939 (Okop).

124 Numeracja odnosi się do wyliczonej wcześniej „Treść śpiewnej”. 
- Zastępca

- Przodownik _ - VI

- Sekretarz

- Skarbnik

Wykładowcy:

Ideologia R.[eduty]

Statut R.[eduty]

Regulamin R.[eduty]

Odcinki: Bibliot.[eka]

Archiw.[um]

Zbiory

Sprzęt

$\underline{\text { W.I.R. }}^{125}$

Przyj.[aciele] R.[eduty] taniec

Geografia Pol.[ski]

Sprawy kolej.[owe]

Ćwiczenia:

oddech

gim.[nastyka] ruch.[owa]

gim.[nastyka] rytm.[ika]

Regulamin W.I.R.

Pok.[azy] Stoł.[eczne]

wymowa R.[edutowa]

Pok.[azy] Szk.[olne]

Pok.[azy] Obj.[azdowe] obyczaje

Okop

Regulamin Okopu

śpiew

milczenia

symetryczn.[ość]

zwyczaje

Literatura Okopu

Słownictwo Okopu

Hist.[oria] teatru pol.[skiego]

Bogusławski

Hist.[oria] lit.[eratury] pol.[skiej]

Mickiewicz

Słowacki

Krasiński

Norwid

Wyspiański

Fredro

ZASP

${ }^{125}$ W.I.R. - Warszawski Instytut Reduty, Osterwa stosował ten skrót w swoich przedwojennych notatkach. W zeszycie z objazdu z Powrotem Przetęckiego Jerzego Zawieyskiego (29 V-30 VII 1939) zapisał pod datą 28 VI 1939: „Myślę propagować to pojęcie o Reducie - i nazwę W.I.R. «Pokazy Objazdowe W.I.R». Pomysł tej nazwy powstał w Sandomierzu. Wir $=$ mąż, Wir $=$ my, Wir $=$ malstrom”. 
Kalendarz w Redutowej pracy

Zasada: w niedziele wstrzymywać się od pracy zarobkowej. Święta święcić. Dnie uroczyste uczcić.

We wrześniu 1939 roku - mamy 4 niedziele

w październiku -5 niedziel

$\underline{\mathrm{w} \text { listopadzie }}-4$ niedziele

i święta: Wszystkich Świętych - 1 XI środa Dziady, Wesele

Dzień zaduszny - 2 XI czwartek

Święto Niepodległości - 11 XI sobota Wyzwolenie - uroczystość albo zamknąć

w grudniu -5 niedziel

Święta: 8 XII piątek Niep.[okalanego Poczęcia] NMP

24 niedziela - wilija w sobotę

25 poniedz.[iałek]

26 wtorek

L. B. Nar. [?] mieszczą się - w wywczasach świątecznych, które rozpoczniemy na odcinku „P.[okazów] St.[ołecznych]” od 21 XII do 26 I

\section{Ćwiczenia mimiczne [pusta karta]}

- Ćwiczenia ruchowe
A. Gimnastyka szwedzka:
1. rąk, 2. nóg, 3. tułowia, 4. barku, 5. głowy
B. Gimnastyka kosowska:
masaż własnego ciała
C. Gimnastyka Okopowa:
ręce - chwytanie much i moli
golenie, wachlowanie
strzepywanie kropel wody - pożegnania na dworcu
pisanie na maszynie, gra na fortepianie

ramiona - malowanie ścian, mycie podłogi, szycie dratwą, prasowanie

otwieranie drzwi (zatrzaśniętych) i zamykanie zepsutych

podnoszenie walizek i zdejmowanie

ukłony kapeluszem, saluty wojskowe, łowienie ryb

nogi - rysowanie palcami nóg, ,ostrogą”, wejście na drabinę

wsiadanie na konia, kłusowanie

siadanie, zakładanie nóg, dygi, klękanie, kopanie piłki

rower, narty, taczki, wiosłowanie, pływanie, tenis

rąbanie drew, dzwonienie, koszenie trawy

spanie na ziemi, leżenie krzyżem, omdlenie i wstawanie

głowa - ,tak” i „,nie”, „ho - ho”, ,nie wiem”, ,całowanie”, „rozpaczanie”

we dwójkę - piłowanie drzewa, przeciąganie prześcieradła, podnoszenie w górę

przepychanie, branie na grzbiet, zapasy atlet.[yczne], szermierka 
zbiorowe - siatkówka

chór - marsz wojskowy, defilada, bieg, wyścig, krakowiak, kołomyjka

\section{Zwyczajowy plan zajęć Okopu w objeździe ${ }^{126}$}

8.30 gimnastyka

9. golenie - mycie - śniadanie - sprzątanie łóżek

10. sprawy organizacyjne objazd.[owe] - w wagonie - sprawozdania

12. sprawy org.[anizacyjne] obj.[azdowe] - zewnątrz wagonu

14. obiad wspólny - informacje kierownictwa grupy

16. odpoczynek indywidualny - czytanie książek, pisanie listów

- drzemka

- gra w szachy, warcaby, pikieta, domino

- spacery, wycieczki wspólne, zwiedzanie

- kąpiel wspólna

- odwiedziny, wizyty

17. ćwiczenia org.[anizacyjne] Okopowe

18. przygotowania do pracy art.[ystycznej] w wagonie

19. przygotowania do pracy art.[ystycznej] na miejscu

20. udział w pokazie

23. posiłek wieczorny

1. gaszenie światła

Ćwiczenia org.[anizacyjne] Okopowe odbywają się między 17 a 18

\section{Zasady wynagrodzenia w objeździe}

Po strąceniu opłat podatkowych, za salę, za kolej i za tantiemę autorską i występ gościnny, netto dzieli się na dwie części. 60\% pobiera Reduta, na koszta lokalne (przewozy itd.), koszta wystawy - organizację, propagandę, zespół techn.[iczny], towarzystwo 5\%, opiekę artyst.[yczną] i wydatki gospodarcze, resztę 40\% dzieli między siebie zespół wykonawczy.

Sumę wynikającą z zysku 40\% netta dzieli się na tę ilość punktów, która pozostaje ze sumowania punktów należnych poszczególnym wykonawcom.

Redutowiec ma prawo do 6 punktów

Ochotnicy wielokrotni do 5 punktów - Zespołowcy

Ochotnicy-nowicjusze i [skreślone - kandydaci] Przodownik Okopu do 4 punktów

Uczniowie starsi do 3 punktów

Uczniowie młodsi do 2 punktów

* miarą jest jeden punkt przyznany wykonawcy technicznemu za pracę techniczną, fizyczną (1/2 punkta pomocnikowi)

${ }^{126}$ Dwa kolejne zapisy ukazały się w wydaniu książkowym: J. Osterwa, Dzienniki wypraw..., op. cit. Tam też czytelnik znajdzie więcej notatek dotyczących praktyk okopowców w objeździe. 
- Za ochotnika wielokr.[otnego] uważa się uczestnika, który objeżdża z Redutą Ziemie Polskie - wielokrotnie - w kilku postaciach - począwszy od $1938 \mathrm{r}$.

- Poza należnością uczestnicy mogą otrzymać wynagrodzenie specjalne z kasy Zespołu Reduty na wniosek kierownika grupy i kierownika odcinka „pokazów szkolnych”.

\section{$\underline{\text { Szczepy w Okopie }}$}

Śnieg

Książę Niezłomny

Lilla Weneda

Balladyna

Pierścień wielkiej damy

Fircyk [w zalotach]

Przepiórka

Wesele

Wyzwolenie

Złota Czaszka

Sen srebrny Salomei

Ksiadz Marek

Wasy i peruka

Cyd

Bolestaw Śmialy 